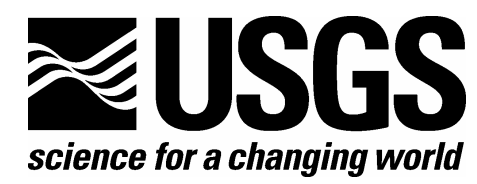

Grand Canyon Monitoring and Research Center, in cooperation with SWCA Environmental Consultants, Inc.

\title{
Comparisons of Water Quality and Biological Variables from Colorado River Shoreline Habitats in Grand Canyon, Arizona, under Steady and Fluctuating Discharges from Glen Canyon Dam
}

By Barbara E. Ralston', Matthew V. Lauretta', and Theodore A. Kennedy'

Open-File Report 2007-1195

2007 


\title{
U.S. Department of the Interior DIRK KEMPTHORNE, Secretary
}

\author{
U.S. Geological Survey \\ Mark D. Myers, Director
}

U.S. Geological Survey, Reston, Virginia 2007

For product and ordering information:

World Wide Web: http://www.usgs.gov/pubprod

Telephone: 1-888-ASK-USGS

For more information on the USGS - the Federal source for science about the Earth, its natural and living resources, natural hazards, and the environment:

World Wide Web: http://www.usgs.gov

Telephone: 1-888-ASK-USGS

Suggested citation:

Ralston, B.E., Lauretta, M.V., Kennedy, T.A., 2007, Comparisons of water quality and biological variables from Colorado River shoreline habitats in Grand Canyon, Arizona, under steady and fluctuating discharges from Glen Canyon Dam: U.S. Geological Survey Open File Report 2007-1195 [http://pubs.usgs.gov/of/2007/1195/].

Keywords: Colorado River, fluctuating and steady releases, macroinvertebrate densities, water quality

Any use of trade, product, or firm names is for descriptive purposes only and does not imply

endorsement by the U.S. Government.

Although this report is in the public domain, permission must be secured from the individual copyright owners to reproduce any copyrighted material contained within this report. 


\section{Contents}

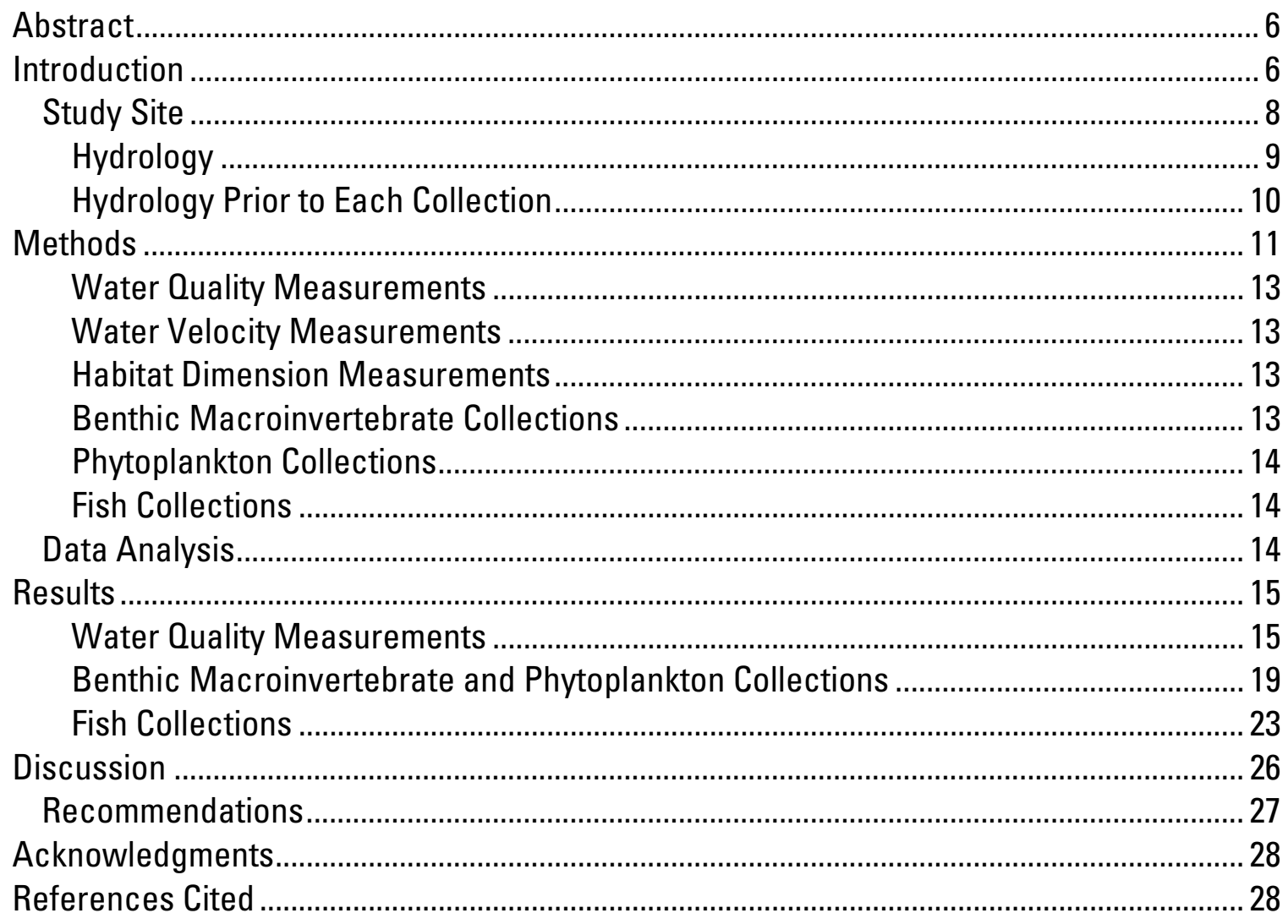

\section{Figures}

Figure 1. Map of sampling area from Lees Ferry, Ariz., to Diamond Creek, Ariz. 9 Figure 2. Hydrograph showing daily mean, minimum and maximum discharge at Lees Ferry, Ariz., from August 15, 2005 to October 22, 2005. Arrows indicate dates of sample collection under fluctuating and steady releases (September 4, 2005-September 16, 2005 and September 22-0ctober 7, 2005).

Figure 3. Water quality parameters: a.) water temperature, b.) salinity, c.) dissolved oxygen, d.) conductivity, e.) water velocity, f.) turbidity, and g.) $\mathrm{pH}$ measured in backwaters (BW mouth, BW center, and BW end) and the mainstem.

Figure 4. Bar graphs comparing macroinvertebrate densities sampled from a.) backwaters and b.) shorelines during fluctuating and steady releases in September and October 2005 (abbreviations for taxa provided below fig. b).

Figure 5. Bar graphs comparing phytoplankton densities sampled from a.) backwaters and b.) shorelines during fluctuating and steady releases in September and October 2005. 
Figure 6. Benthic invertebrate density by site under fluctuating and steady releases with distance from Glen Canyon Dam for a.) backwaters and b.) shoreline habitats (difference between treatments were non significant).

Figure 7. Catch-per-unit-effort (CPUE) for fish species encountered from a.) backwater seining and b.) shoreline backpack shocking under fluctuating and steady releases in September and October 2005 (abbreviations for species provided below fig. b).

Figure 8. Catch-per-unit-effort (CPUE) for fish species encountered from a.) backwater seining and $b$.) shoreline backpack shocking under fluctuating and steady flow treatments with distance from Glen Canyon Dam (difference between treatments were non significant).

\section{Tables}

Table 1. Maxima, minima, and range of discharge during collection periods September 4, 2005-0ctober 7, 2005, as recorded at Lees Ferry, Ariz. Data are based on 15-minute recorded values (http://www.gcmrc.gov/products/flow_data accessed 06/25/2006). ........11

Table 2. Sample dates, numbers, and locations (river km) of paired shoreline and backwater sites.

Table 3. Average values of water quality parameters from three locations in backwaters (mouth, center, and end) and adjacent mainstem (MS) habitats.

Table 4. Summary statistics of macroinvertebrate densities from backwaters and shoreline habitats under fluctuation and steady releases from September 4 to 0 ctober 7 , 2005 (abbreviations for taxa provided below table). 


\section{Conversion Factors}

Inch/Pound to SI

\begin{tabular}{|c|c|c|}
\hline Multiply & By & To obtain \\
\hline \multicolumn{3}{|c|}{ Length } \\
\hline inch (in.) & 2.54 & centimeter $(\mathrm{cm})$ \\
\hline mile (mi) & 1.609 & kilometer (km) \\
\hline \multicolumn{3}{|c|}{ Area } \\
\hline square foot $\left(\mathrm{ft}^{2}\right)$ & 929.0 & square centimeter $\left(\mathrm{cm}^{2}\right)$ \\
\hline square foot $\left(\mathrm{ft}^{2}\right)$ & 0.09290 & square meter $\left(\mathrm{m}^{2}\right)$ \\
\hline square inch $\left(\right.$ in $\left.^{2}\right)$ & 6.452 & square centimeter $\left(\mathrm{cm}^{2}\right)$ \\
\hline \multicolumn{3}{|c|}{ Volume } \\
\hline ounce, fluid (fl. oz) & 0.02957 & liter (L) \\
\hline pint (pt) & 0.4732 & liter (L) \\
\hline quart (qt) & 0.9464 & liter (L) \\
\hline gallon (gal) & 3.785 & liter (L) \\
\hline cubic foot $\left(\mathrm{ft}^{3}\right)$ & 0.02832 & cubic meter $\left(\mathrm{m}^{3}\right)$ \\
\hline \multicolumn{3}{|c|}{ Flow rate } \\
\hline foot per second (ft/s) & 0.3048 & meter per second $(\mathrm{m} / \mathrm{s})$ \\
\hline cubic foot per second $\left(\mathrm{ft}^{3} / \mathrm{s}\right)$ & 0.02832 & cubic meter per second $\left(\mathrm{m}^{3} \mathrm{~s}^{-1}\right)$ \\
\hline
\end{tabular}

Temperature in degrees Celsius $\left({ }^{\circ} \mathrm{C}\right)$ may be converted to degrees Fahrenheit $\left({ }^{\circ} \mathrm{F}\right)$ as follows:

${ }^{\circ} \mathrm{F}=\left(1.8 x^{\circ} \mathrm{C}\right)+32$.

Specific conductance is given in microsiemens per centimeter at 25 degrees Celsius $\left(\mu \mathrm{S} / \mathrm{cm}\right.$ at $\left.25^{\circ} \mathrm{C}\right)$. Concentrations of chemical constituents in water are given either in milligrams per liter $(\mathrm{mg} / \mathrm{L})$ or micrograms per liter $(\mu \mathrm{g} / \mathrm{L})$. 


\section{Comparisons of Water Quality and Biological Variables from Colorado River Shoreline Habitats in Grand Canyon, Arizona, under Steady and Fluctuating Discharges from Glen Canyon Dam}

By Barbara E. Ralston, Matthew V. Loretta, and Theodore A. Kennedy

\section{Abstract}

Glen Canyon Dam operations are known to affect mainstem Colorado River temperature and shoreline habitats for native fish. Options for ameliorating the impacts that operations have on young native fish include changing release volumes and/or changing the daily range of releases. Long-term alterations of operations that may produce a measurable biological response can be costly, particularly if the treatment involves reduced power generation. In September and October 2005, a series of twoweek releases occurred that alternated between daily fluctuations that varied by $76 \mathrm{~m}^{3} \mathrm{~s}^{-1}$ and steady releases. The purpose of these short-term experiments was to study the effect of daily operations on water quality parameters and biotic constituents (phytoplankton, macroinvertebrates, and fishes) of associated shoreline habitats. Our results indicate that measured biological and physical parameters were, in general, unaffected by flow treatments. However, results should be interpreted cautiously as time within and between treatments was likely insufficient to affect measured parameters. These results lead to the recommendation that studies like this may be more amenable to laboratory experiments first and then applied to a large-scale setting, preferably for longer duration.

\section{Introduction}

Glen Canyon Dam operations are known to affect mainstem Colorado River temperature and shoreline habitats for fish. Recruitment failure by native fish in the Colorado River in Grand Canyon has been attributed to habitat loss associated with reduced mainstem temperatures and unstable shorelines, among other factors (Kaeding and Zimmerman, 1983; Gorman and Stone, 1999). Cold mainstem temperatures (8$12^{\circ} \mathrm{C}$ ), influenced by reservoir elevations and release volume (Vernieu and others, 2005), reduce growth rates of larvae and young-of-year fishes and prevent or reduce mainstem spawning success (Robinson and Childs, 2001; Korman and others, 2005). In Glen Canyon, habitat instability associated with daily fluctuations or changes in base flow is 
connected with displacement of nonnative young-of-year rainbow trout (Oncorhynchus mykiss), which results in mortality or exposure of young fish to predation (Korman and others, 2005); the same may be true for native fishes downstream of Lees Ferry (Korman and others, 2004). Stone and Gorman (2006) found that young-of-year humpback chub (Gila cypha), an endangered species, occupied stable, shallow, near-shore habitats in the Little Colorado River.

Options for ameliorating Glen Canyon Dam impacts on young fish include altering how much water is released and/or changing the daily range of the releases. Reducing the discharge of releases allows for greater mainstem warming, while stabilizing or reducing daily fluctuations in discharge allows for greater nearshore warming. To date, several short duration tests of alternative releases have occurred from Glen Canyon Dam. Short duration, experimental high flow releases beyond power plant capacity have occurred twice, in 1996 (7 days in March at $\left.1274 \mathrm{~m}^{3} \mathrm{~s}^{-1}\right)$ and 2004 (60 hours in November at $\left.1160 \mathrm{~m}^{3} \mathrm{~s}^{-1}\right)$, principally to study sediment transport and storage (Rubin and others, 2002; Topping and others, 2006). Additionally, power plant capacity maintenance flows (24 hours at $877 \mathrm{~m}^{3} \mathrm{~s}^{-1}$ ) occurred once in 1997 and twice in 2000. These high flow releases have increased our understanding of physical resource responses to dam operations. However, the responses of biological resources to these short duration operations remain unclear. Cause and effect relationships are more difficult to identify for biological resources as these short-term flow events may differentially affect life stages with the responses expressed several years later, if at all. Longer term alterations of operations (e.g., months), which may produce a measurable biological response, can be costly, particularly those that reduce power generating potential. As with short term events, their impact may not be observable for several years.

A single longer-term experiment of steady flows that targeted native fish species occurred in the summer of 2000 (Trammell and others, 2002). These flows may have increased mainstem spawning success and survivorship of juvenile native fishes by increasing mainstem and nearshore water temperatures and stabilizing nearshore habitats. The Grand Canyon fish monitoring program started observing higher densities of adult native fish in 2005 (Melis and others, 2006), indicating that recruitment into the adult native fish populations, an important measure of whether an experiment or management action benefits native fishes, may have increased as a result of the 2000 experiment. The five-year response lag measured for native fish compared with the relatively instantaneous response by sediment resources illustrates how treatment duration influences response and how our ability to measure response varies by resource.

Reconciling and balancing resource needs associated with adaptive management for Glen Canyon Dam is an ongoing process. Improvement of downstream resources associated with managed operations can only be achieved through experimental approaches coupled with resource monitoring that include variation in time of treatment as prescribed by the adaptive management process (Holling, 1978). In an attempt to determine whether minor daily fluctuations in discharge that allow for greater power generation, compared to steady flow releases, have the same effects on water quality and aquatic organisms, the Bureau of Reclamation implemented a series of two-week operations that alternated between steady and fluctuating flows in September and October 2005. The alternating two-week scenario followed summer operations (JuneAugust) in which daily operations fluctuated by approximately $226 \mathrm{~m}^{3} \mathrm{~s}^{-1}$. 
The motivation for this experiment was to determine whether nearshore physical and biological variables are affected by steady flows relative to low daily fluctuations (daily range of $74 \mathrm{~m}^{3} \mathrm{~s}^{-1}$ ) in flow. We hypothesized that during steady flows, nearshore environments would be more stable and allow for greater nearshore warming. Stable nearshore environments might also promote growth of lower trophic levels, leading to higher abundance or biomass. Daily fluctuations might force young fish to move among and within habitats, so we also hypothesized that relative abundance of young fishes occupying nearshore environments might be higher during stable flows relative to low fluctuations. For example, Korman and others (2005) have shown that changing base flow conditions and greater daily range in volumes result in significantly lower relative abundance for young-of-year (YOY) rainbow trout in Glen Canyon. We also hypothesized that backwaters might show a larger change in water quality and biological parameters during steady flows relative to other nearshore environments because steady flows will increase the residence time of water there, thereby promoting warming.

To evaluate these hypotheses we quantified water quality and biological variables in backwaters and adjacent nearshore environments during the September and October 2005 experimental flows. The null hypothesis was that there would be no difference in water quality or biological parameters among habitats or among flow treatments. Antecedent conditions of measured parameters were not measured prior to the start of the first flow treatment of low fluctuations.

\section{Study Site}

Data were collected at 12 different sites between Lees Ferry [river kilometer (RK) 15] and Diamond Creek (RK 360; fig. 1) under each treatment for a total of 24 sites. Along this reach, the river channel passes through 13 bedrock-controlled reaches that vary in width and depth as influenced by the underlying bedrock (Schmidt and Graf, 1990). Within Grand Canyon there are 740 tributaries that produce debris-fan eddy complexes (Schmidt and Graf, 1990; Griffiths and others, 2004), which form constrictions and associated rapids along the river. Most tributaries are intermittent rather than having a permanent source of water entering the mainstem Colorado River. The compass orientation of the river in the canyon varies from east-west and north-south, which affects available light for primary production (Stevens and others, 1997; Yard and others, 2005). 


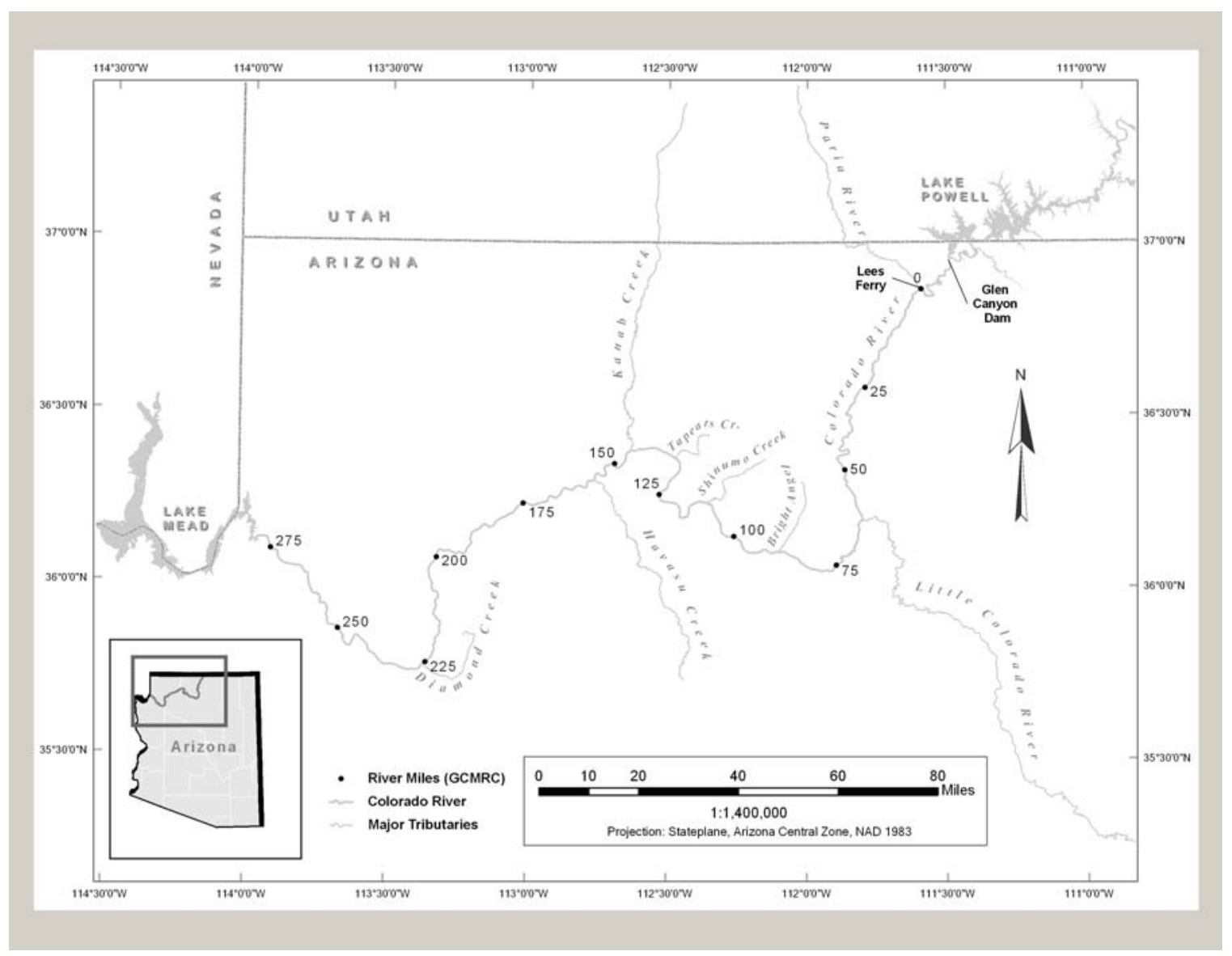

Figure 1. Map of sampling area from Lees Ferry, Ariz., to Diamond Creek, Ariz.

The shoreline consists of sand, cobble, talus/boulder, and ledges. The sandy shorelines can be vegetated and, if associated with a debris fan, may form return current channel sandbars in an up- or downstream direction that is termed a "backwater." Backwaters along the Colorado River in Grand Canyon differ from backwaters in alluvial systems (e.g., the Green River near Vernal, Utah) by being smaller in size (e.g., 100-500 $\mathrm{m}^{2}$ vs. $3,000 \mathrm{~m}^{2}$ or greater), consistently open to exchange with the mainstem, and are more ephemeral depending on the amount of sand storage in the eddy complex and discharge volume (Goeking and others, 2003).

\section{Hydrology}

Discharge of the Colorado River through Glen Canyon National Recreation Area and Grand Canyon National Park is regulated by Glen Canyon Dam. In 1995 (U.S. DOI, 1995), operational constraints were placed on Glen Canyon Dam, and since then, the median annual discharge measured at the U.S. Geological Survey gage at Lees Ferry (USGS gage number 09380000) has been $378 \mathrm{~m}^{3} \mathrm{~s}^{-1}$ (Topping and others, 2003). The median daily range associated with daily fluctuations around the discharge has been 138 $\mathrm{m}^{3} \mathrm{~s}^{1}$ since 1996 .

Side tributaries periodically contribute sediment and coarse organic matter to the main channel. Generally these inputs are delivered from July to September (Griffiths and 
others, 2004) and are associated with summer convective thunderstorms created by moist air originating in the Gulf of Mexico or the Pacific Ocean, locally called "monsoonal rains." While not all storms result in debris flows, the amount of rain falling is sufficient to generate local sediment and coarse particulate matter inputs or "spates" periodically within the Colorado River ecosystem (CRE). The directional pattern of monsoon storms trends from southwest to northeast across the canyon. Tributaries within the CRE have greater sediment loads than those tributaries associated with the Colorado River above Glen Canyon Dam or the Green River (Andrews, 1991).

\section{Hydrology Prior to Each Collection}

Releases in August, immediately prior to the experimental flow treatments we studied, had a daily peak discharge of $532 \mathrm{~m}^{3} \mathrm{~s}^{-1}$, a daily minimum of $294 \mathrm{~m}^{3} \mathrm{~s}^{-1}$, and a daily range of $237 \mathrm{~m}^{3} \mathrm{~s}^{-1}$. From September 1 to 3, 2005, the daily range and daily minima were slowly reduced to transition between the higher volume and wider fluctuating August releases and the more constrained September release pattern (fig. 2). During the months of September and October 2005, water was released from Glen Canyon Dam that alternated between fluctuating and steady releases. The dates for fluctuating releases were from September 4 to 22, 2005, and steady releases occurred from September 22 to October 7, 2005 (fig. 2). Data were collected between the dates of September 4-16, 2005 and September 22-October 7, 2005. Release maxima and minima and range for data collection dates are provided in table 1 . Antecedent hydrology, which can influence biological and water quality parameters, for the first treatment included large fluctuations from August and potential sediment inputs associated with monsoonal activity. The antecedent conditions for the steady flow treatment include the reduced flows that began on September 4, 2005. 


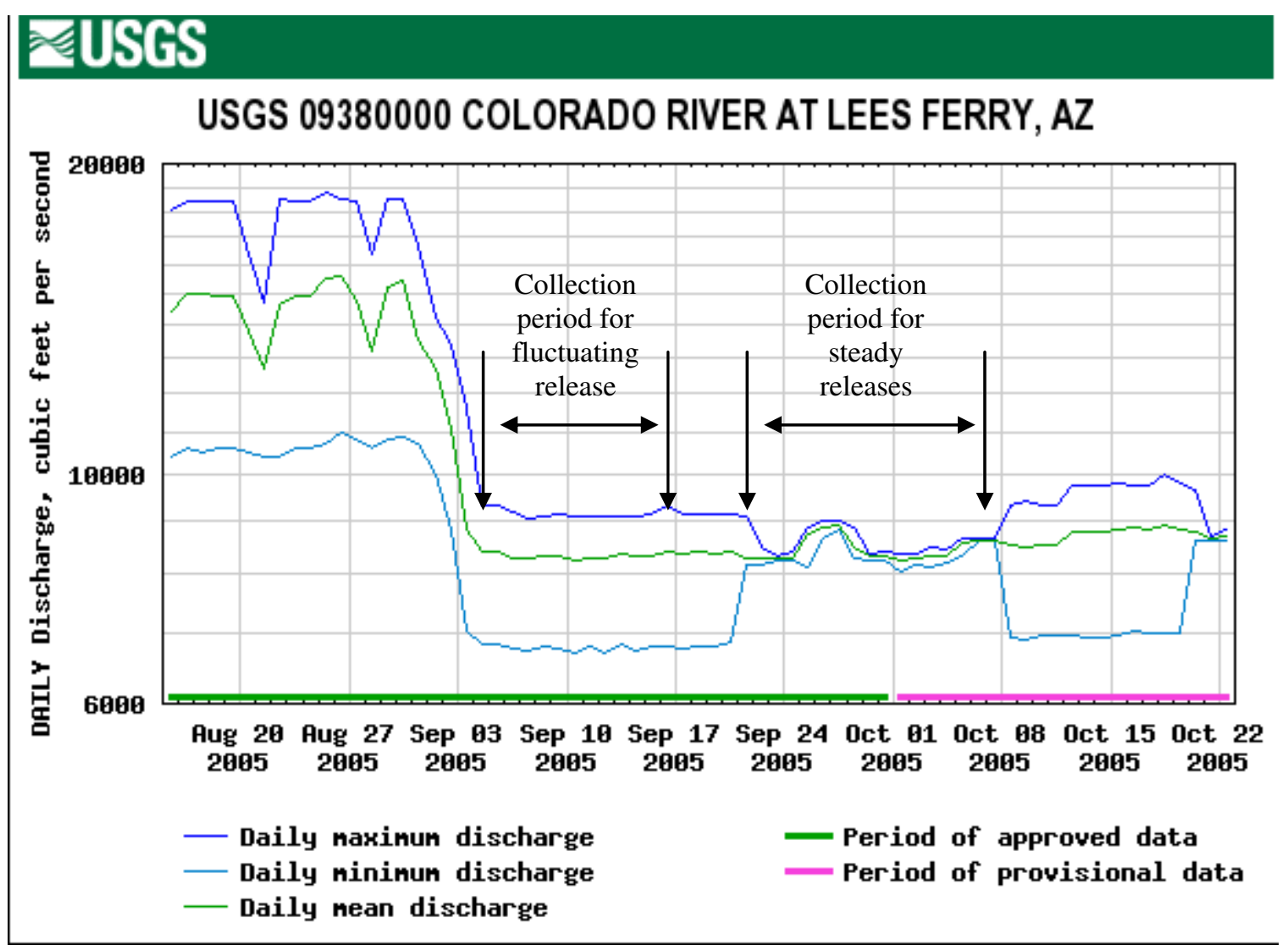

Figure 2. Hydrograph showing daily mean, minimum and maximum discharge at Lees Ferry, Ariz., from August 15, 2005 to October 22, 2005. Arrows indicate dates of sample collection under fluctuating and steady releases (September 4, 2005-September 16, 2005 and September 22-0ctober 7, 2005).

Table 1. Maxima, minima, and range of discharge during collection periods September 4, 2005-0ctober 7, 2005, as recorded at Lees Ferry, Ariz. Data are based on 15-minute recorded values (http://www.gcmrc.gov/products/flow_data.aspx accessed 06/25/2006).

\begin{tabular}{|l|l|l|l|l|c|}
\hline Collection Dates & $\begin{array}{l}\text { Flow } \\
\text { Release } \\
\text { Pattern }\end{array}$ & $\begin{array}{l}\text { Maximum } \\
\text { Release } \\
\left(\mathbf{m}^{\mathbf{3}} \mathbf{s}^{-1}\right)\end{array}$ & $\begin{array}{l}\text { Minimum } \\
\text { Release } \\
\left(\mathbf{m}^{\mathbf{3}} \mathbf{s}-\mathbf{1}\right)\end{array}$ & $\begin{array}{l}\text { Daily range }\left(\mathbf{m}^{\mathbf{3}}\right. \\
\mathbf{s}-\mathbf{1})\end{array}$ & $\begin{array}{l}\text { Median Release } \\
\left(\mathbf{m}^{\mathbf{3}} \mathbf{s}^{-1}\right)\end{array}$ \\
\hline \multicolumn{7}{|l|}{} \\
\hline $\begin{array}{l}09 / 04 / 2005- \\
09 / 16 / 2005\end{array}$ & Fluctuating & 263 & 189 & 74 & 250 \\
\hline $\begin{array}{l}09 / 22 / 2005- \\
10 / 07 / 2005\end{array}$ & Steady & 255 & 227 & 27 & 236 \\
\hline
\end{tabular}

\section{Methods}

Sample collection included water quality, water velocity, and habitat dimensions for backwaters, benthic invertebrate and plankton density and composition, and fish composition and catch per unit effort (CPUE), a measure of relative abundance. Samples 
were collected at selected sites distributed along 360 river kilometers of shoreline of the CRE from Lees Ferry to Diamond Creek (fig. 1). Sampling included backwaters and adjacent shorelines. Sampling was conducted at 12 paired sites, each composed of a backwater and nearby shoreline habitat. Sites were selected by stratified random sampling within each logistic sampling reach (table 2). Shoreline habitats consisted of vegetated shorelines, talus slopes, boulders, or ledges. In order not to bias the samples from the effects of previous sampling, a random sample of habitats without replacement was selected for each of the trips.

Table 2. Sample dates, numbers, and locations (river $\mathrm{km}$ ) of paired shoreline and backwater sites.

\begin{tabular}{|c|c|c|}
\hline $\begin{array}{c}\text { Sample } \\
\text { Date }\end{array}$ & $\begin{array}{c}\text { Sample Number (site } \\
\text { number) }\end{array}$ & $\begin{array}{c}\text { River km and side }^{1} \\
\text { (Left or Right) }\end{array}$ \\
\hline $09 / 04 / 2005$ & $1(1)$ & $49.3 \mathrm{R}$ \\
\hline 09/05/2005 & $2(2)$ & $71.7 \mathrm{~L}$ \\
\hline 09/06/2005 & $3(3)$ & $82.7 \mathrm{~L}$ \\
\hline 09/07/2005 & $4(4)$ & $105.0 \mathrm{~L}$ \\
\hline 09/10/2005 & $5(5)$ & $192.7 \mathrm{R}$ \\
\hline 09/10/2005 & $6(6)$ & $193.8 \mathrm{R}$ \\
\hline $09 / 11 / 2005$ & 7 (7) & $215.4 \mathrm{R}$ \\
\hline $09 / 11 / 2005$ & $8(8)$ & $221.5 \mathrm{~L}$ \\
\hline $09 / 13 / 2005$ & $9(9)$ & $276.4 \mathrm{~L}$ \\
\hline $09 / 13 / 2005$ & $10(10)$ & $277.7 \mathrm{~L}$ \\
\hline $09 / 14 / 2005$ & $11(11)$ & $305.3 \mathrm{R}$ \\
\hline $09 / 15 / 2005$ & $12(12)$ & $342.7 \mathrm{R}$ \\
\hline $09 / 22 / 2005$ & $13(1)$ & $5.4 \mathrm{~L}$ \\
\hline $09 / 25 / 2005$ & $14(2)$ & $57.2 \mathrm{R}$ \\
\hline $09 / 25 / 2005$ & $15(3)$ & $70.4 \mathrm{~L}$ \\
\hline $09 / 27 / 2005$ & $16(4)$ & $82.7 \mathrm{~L}$ \\
\hline $09 / 27 / 2005$ & $17(5)$ & $110.3 \mathrm{~L}$ \\
\hline 09/29/2005 & $18(6)$ & $150.9 \mathrm{R}$ \\
\hline 09/30/2005 & $19(7)$ & $191.1 \mathrm{R}$ \\
\hline $10 / 01 / 2005$ & $20(8)$ & $213.1 \mathrm{R}$ \\
\hline $10 / 02 / 2005$ & $21(9)$ & $269.5 \mathrm{R}$ \\
\hline $10 / 03 / 2005$ & $22(10)$ & $284.6 \mathrm{R}$ \\
\hline $10 / 04 / 2005$ & $23(11)$ & $291.8 \mathrm{R}$ \\
\hline $10 / 04 / 2005$ & $24(12)$ & $326.4 \mathrm{R}$ \\
\hline
\end{tabular}




\section{Water Quality Measurements}

Because backwater habitats are connected to the mainstem, we were also interested in how water quality parameters might change longitudinally along the backwater. Water quality measurements were taken in three locations at each backwater site (mouth, center, and foot of the backwater) and three locations at other shoreline sites. For comparisons between habitats we compared means of the three backwater measurements to means of shoreline temperatures across sites. Measurements were taken in backwaters after a block net was placed across the mouth and prior to any other sampling. Water temperature, specific conductivity, $\mathrm{pH}$, dissolved oxygen, and salinity were measured using a Eureka Amphibian data logger $\left(\right.$ ) with a Eureka Mantis probe $\left({ }_{\text {. }}\right.$ The data logger was calibrated against standards for water quality measures prior to each trip. Turbidity measurements were taken at each site using a Hydrolab Quanta@. Air temperature was also recorded using a standard thermometer. Water temperature loggers (Hobos@) were placed along five separate shoreline habitats to record water temperature continuously for the duration of the sampling trips. These temperature data are part of a separate data delivery submitted by Kaplinski (2006).

\section{Water Velocity Measurements}

Three water velocity measurements were taken at each site using a MarshMcBirney Flo-Mate (C). In backwaters, after the block net was removed, water velocity was measured at three locations: near the mouth, in the center, and near the foot.

\section{Habitat Dimension Measurements}

The maximum length, maximum width, and maximum depth were recorded at each backwater. Three additional width and length measurements were taken at the mouth, center, and foot to calculate the average backwater width and depth. A quick sketch of the backwater was drawn, the location marked on ortho-photographic maps, and location information recorded.

\section{Benthic Macroinvertebrate Collections}

Macroinvertebrates were collected at each backwater using a Petit Ponar Grab Sampler@ with a sampling area of $0.0231 \mathrm{~m}^{2}$ (Wildlife Supply Company, Buffalo, N.Y.) and at each shoreline using a Hess Sampler@ (0.33 $\mathrm{m}$ in diameter and $0.45 \mathrm{~m}$ high, sampling area $=0.0855 \mathrm{~m}^{2}$ ) equipped with a 500-micron mesh net. Macroinvertebrates were collected following the water quality measurements. Backwater samples were strained through a 500-micron sieve so that Ponar and Hess samples would be comparable. It was not possible to use the same sampler in both habitats because Hess samplers perform best in environments with current (i.e., shorelines), and a Ponar sampler is only suitable for sandy substrates (i.e., backwaters). At shoreline sites, the Hess sampler was pushed into the substrate and the substrate bottom stirred up. The organisms were washed into the collection bag by the current flowing through the front screen opening. Each sample was stored in a 1.89-L plastic jar with $70 \%$ ethanol added to 
preserve the organisms. Macroinvertebrate samples were identified to family, and counts per area sampled were calculated.

\section{Phytoplankton Collections}

Plankton samples were collected at 10 paired sites during each sampling trip (20 samples per trip) after water quality and macroinvertebrate samples were collected. Plankton was collected at each site by straining $50 \mathrm{~L}$ of water through a Fieldmaster Student Plankton Net $\subset$ (0.20-m diameter, 1.29-m length, and 80-micron mesh). A 10-L bucket was used to collect water that was poured through the plankton net. A wash bottle was used to rinse the strained sample to the bottom of the net, rinsing from the outside of the net to insure that no additional plankton was caught during rinsing. The plankton was collected in a 250-ml sample bottle attached to the end of the net. Lugol's iodine solution was added as a sample preservative. Aquatic Consulting and Testing Inc. conducted phytoplankton analyses including composition and counts $/ \mathrm{ml}$ of sample. The counts were converted to numbers per volume sampled. When available, algae grab samples were collected at each site to identify species.

\section{Fish Collections}

The mouth of each backwater was blocked with a 9.14-m block net (1.83-m height $x$ 25-mm mesh size), and seining was conducted at each backwater using a 9.14-m bag seine (25-mm mesh size, $1.83-\mathrm{x} 1.83-\mathrm{x} 1.83-\mathrm{m}$ bag) after other sample collections. Three depletion passes with the 9.14-m bag seine were taken at each backwater in order to estimate fish density. Seine haul length and three depth and width measurements were recorded for each sample. All fish were identified and total lengths measured. The CPUE of each species was calculated for each sample [\# of fish/backwater area seined $\left(\mathrm{m}^{2}\right)$, first pass].

Adjacent shorelines were sampled with a Smith Root LR-24 backpack electrofisher(O). One electrofishing pass was made along the shoreline and CPUE (fish/100 s) calculated. Fish were handled following established protocols for Grand Canyon. Additionally, fish specimens were collected for otolith analyses and included up to 20 speckled dace (Rhinichthys osculus), 20 flannelmouth suckers (Catostomus latipinnis), all fathead minnow (Pimephales promelas), all plains killifish (Fundulus zebrinus), and all rainbow trout per trip. All fish collected were less than $60 \mathrm{~mm}$ in total length for daily otolith growth analysis. Preservation of fish specimens follows Korman and others (2005). These samples remain preserved for analysis at a future date if the availability of funds allows.

\section{Data Analysis}

To determine if measured parameters differed between treatments, we used a onesided Student's t-test with unequal variances. Analysis was done using Excel algorithms (Microsoft@ Office Excel, 2003). To determine if there was any dissimilarity between habitats for macroinvertebrates or fishes, we ran a Mantel test in PC-ORD (McCune and Mefford, 1999). The Mantel test used Pearson's correlation to relate the distance matrices (shoreline vs backwaters under fluctuating and steady flow treatments). The distance 
measures were obtained with Sorensen (Bray-Curtis) distances. The runs consisted of 999 permutations using the Monte Carlo randomization method.

\section{Results}

\section{Water Quality Measurements}

Except for turbidity $\left(\bar{X}\right.$ turb $_{\text {treatment } 1}=22.1 \mathrm{ntu}, \bar{X}$ turb $_{\text {treatment } 2}=6.48 \mathrm{ntu}, \mathrm{t}_{(0.05,(1), 11)}=$ $3.51, \mathrm{p}=0.02)$, water quality parameters did not differ significantly among treatments (table 3; fig. 3a-g). Temperatures in backwaters were generally lower during steady flows relative to low fluctuations, but the difference was not significant. Water temperatures among backwaters were less variable during steady flows relative to low fluctuations $\left(\bar{X}\right.$ temp treatment $1=19.5^{\circ} \mathrm{C}$, var. $=4.6$ vs. $\bar{X}$ temp $_{\text {treatment } 2}=18.5^{\circ} \mathrm{C}$, var. $=1.9$ ), but again the difference was not statistically significant. Within a given backwater the temperature range averaged $1^{\circ} \mathrm{C}$ during fluctuating flows and $1.4^{\circ} \mathrm{C}$ during steady flows with the warmest water located the farthest from the backwater opening. Under fluctuating flows, dissolved oxygen concentrations declined farther from the backwater opening. Under steady flows, dissolved oxygen concentrations increased with distance from the backwater opening, but the differences in dissolved oxygen values between mouth and ends of backwaters recorded were within the error limits of the instrument. Water quality parameters did not differ significantly along shorelines among treatments except for turbidity, which was significantly lower during the second treatment along the shoreline $\left(\bar{X}\right.$ turb $_{\text {treatment } 1}=25.2 \mathrm{ntu}, \bar{X}$ turb $\left._{\text {treatment } 2}=3.87 \mathrm{ntu}, \mathrm{t}_{(0.05,(1), 1)}=3.74, \mathrm{p}=0.001\right)$. Shoreline temperatures did not differ significantly between sampling treatments. Mean shoreline temperatures averaged $0.8^{\circ} \mathrm{C}$ lower during the steady flow treatment relative to low fluctuating treatment. The range of the mean sample variance was smaller during the second treatment, but not significantly different $\left(\bar{X}\right.$ temp $_{\text {treatment } 1}=18.1^{\circ} \mathrm{C}$, var. $=1.73 \mathrm{vs}$. $\bar{X}$ temp treatment $2=17.2^{\circ} \mathrm{C}$, var. $=0.79$ ). Water velocity along shorelines was higher during steady flows than fluctuating flows, but the difference was not significant. 

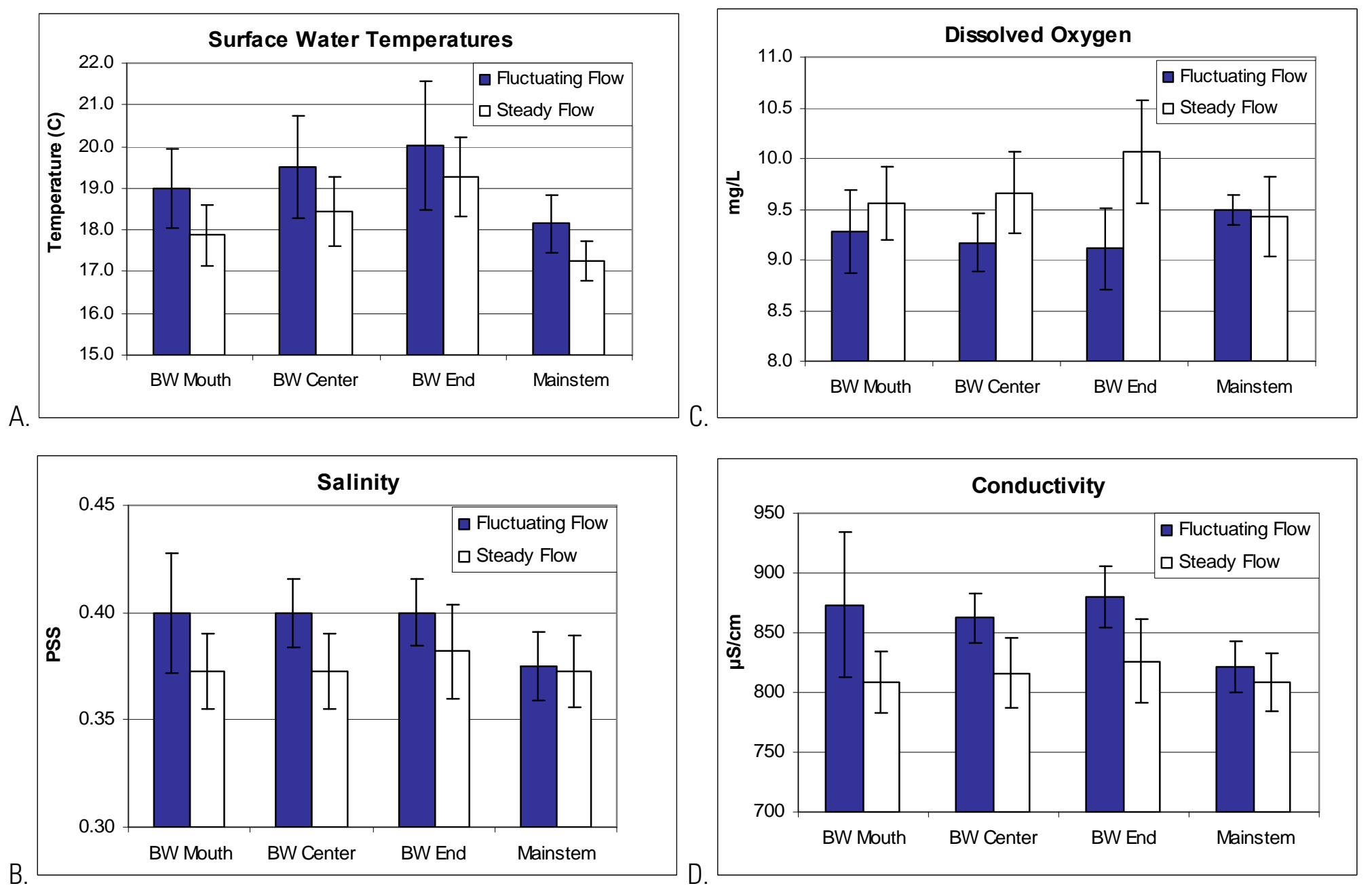

Figure 3. Water quality parameters: a.) water temperature, b.) salinity, c.) dissolved oxygen, d.) conductivity, e.) water velocity, f.) turbidity, and g.) pH measured in backwaters (BW mouth, BW center, and BW end) and the mainstem. 


\section{Figure 3 continued}

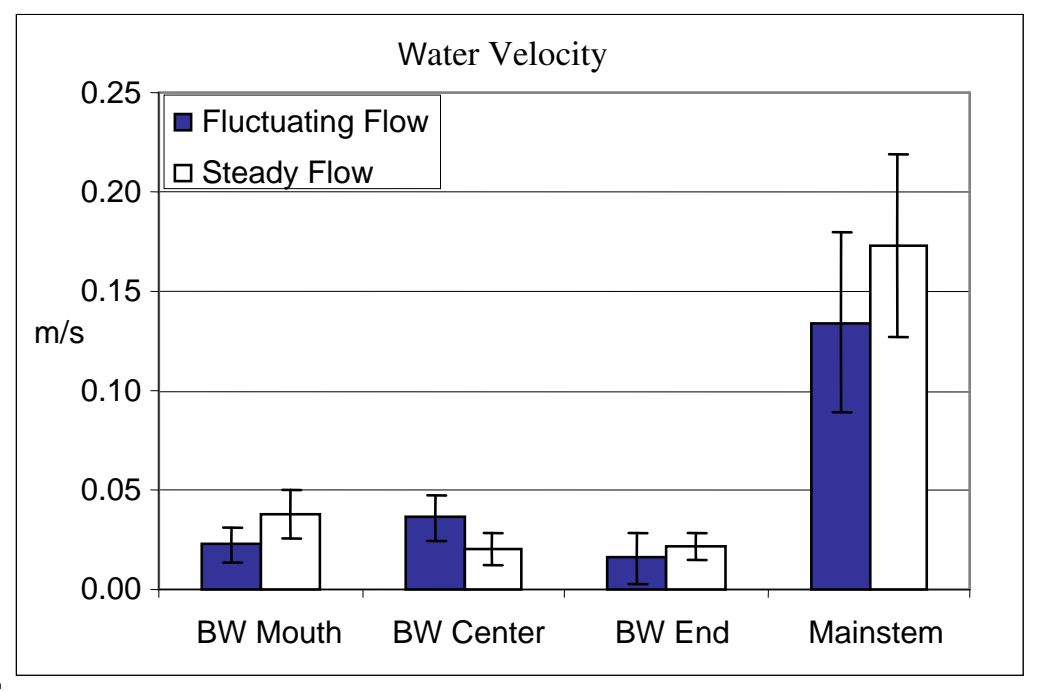

e.

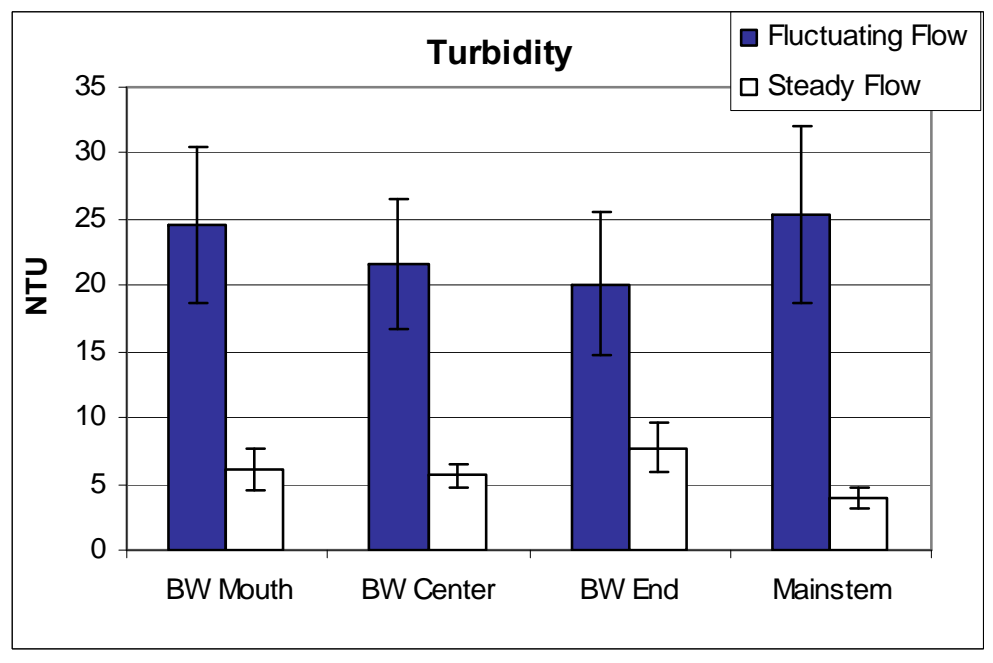

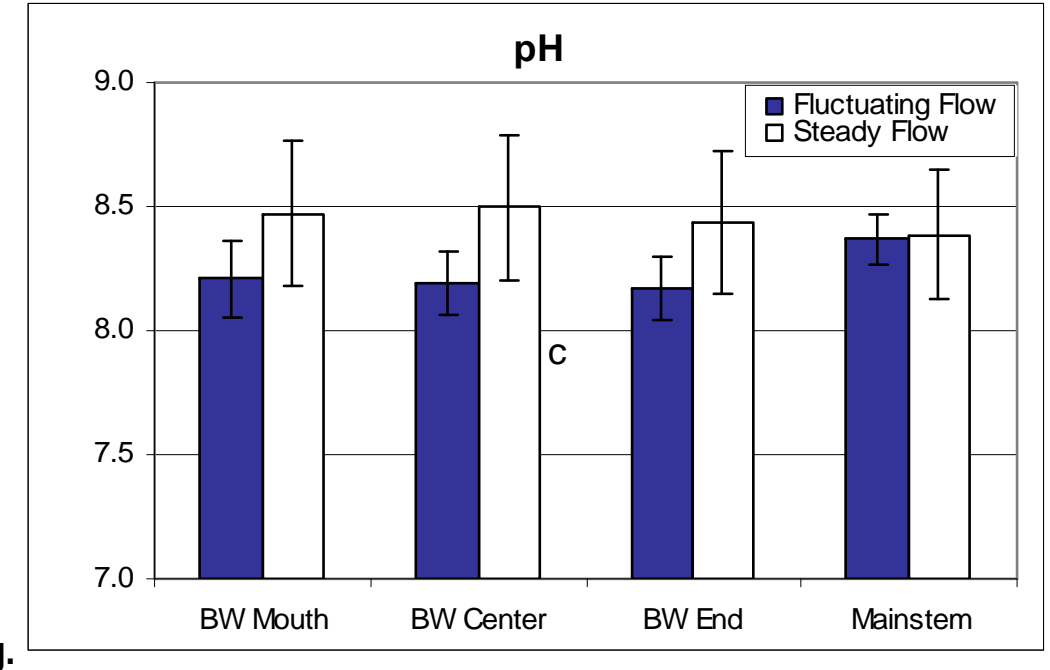

g. 
Table 3. Average values of water quality parameters from three locations in backwaters (mouth, center, and end) and adjacent mainstem (MS) habitats.

\begin{tabular}{|l|l|c|c|c|c|c|c|c|c|}
\hline \multirow{2}{*}{ Averages } & & \multicolumn{3}{|c|}{ Surface $\mathbf{H}_{2}$ OTemp $\left({ }^{\circ} \mathbf{C}\right)$} & \multicolumn{4}{c|}{ Dissolved Oxygen (mg/L) } \\
\hline \multirow{4}{*}{ Fluctuating flow } & & Mouth & Center & End & MS & Mouth & Center & End & MS \\
\cline { 2 - 12 } & mean & 19.0 & 19.5 & 20.0 & $18 . *^{1}$ & 9.3 & 9.2 & 9.1 & 9.5 \\
\cline { 2 - 12 } & Stdev & 1.659 & 2.209 & 2.881 & 1.316 & 0.811 & 0.588 & 0.852 & 0.335 \\
\cline { 2 - 11 } & SE & 0.5 & 0.6 & 0.8 & 0.3 & 0.2 & 0.1 & 0.2 & 0.1 \\
\cline { 2 - 11 } & CI (2SE) & 1.0 & 1.2 & 1.5 & 0.7 & 0.4 & 0.3 & 0.4 & 0.2 \\
\hline \multirow{5}{*}{ Steady flow } & & & & & & & & & \\
& mean & 17.9 & 18.4 & 19.3 & $17.3 *$ & 9.6 & 9.7 & 10.1 & 9.4 \\
\cline { 2 - 11 } & Stdev & 1.3 & 1.5 & 1.8 & 0.9 & 0.7 & 0.8 & 1.1 & 0.8 \\
\cline { 2 - 10 } & SE & 0.4 & 0.4 & 0.5 & 0.2 & 0.2 & 0.2 & 0.3 & 0.2 \\
\cline { 2 - 10 } & CI (2SE) & 0.7 & 0.8 & 0.9 & 0.5 & 0.4 & 0.4 & 0.5 & 0.4 \\
\hline
\end{tabular}

\begin{tabular}{|l|l|c|c|c|c|c|c|c|c|}
\hline \multirow{2}{*}{ Averages } & & \multicolumn{4}{|c|}{ Conductivity $(\boldsymbol{\mu S} / \mathbf{c m})$} & \multicolumn{4}{c|}{ pH } \\
\hline & & Mouth & Center & End & MS & Mouth & Center & End & MS \\
\hline Fluctuating flow & mean & 873.3 & 862.6 & 879.9 & 821.7 & 8.2 & 8.2 & 8.2 & 8.4 \\
\cline { 2 - 12 } & Stdev & 136.1704 & 47.53 & 59.39 & 52.18 & 0.379 & 0.323 & 0.338 & 0.254 \\
\cline { 2 - 11 } & SE & 30.4 & 10.4 & 12.7 & 10.9 & 0.1 & 0.1 & 0.1 & 0.0 \\
\cline { 2 - 11 } & CI (2SE) & 60.9 & 20.7 & 25.3 & 21.8 & 0.2 & 0.1 & 0.1 & 0.1 \\
\hline \multirow{5}{*}{ Steady flow } & & & & & & & & & \\
& mean & 808.5 & 816.3 & 826.1 & 808.5 & 8.5 & 8.5 & 8.4 & 8.4 \\
\cline { 2 - 11 } & Stdev & 56.5 & 66.3 & 81.8 & 57.7 & 0.7 & 0.7 & 0.7 & 0.7 \\
\cline { 2 - 10 } & SE & 12.6 & 14.5 & 17.4 & 12.0 & 0.1 & 0.1 & 0.1 & 0.1 \\
\cline { 2 - 10 } & CI (2SE) & 25.3 & 28.9 & 34.9 & 24.1 & 0.3 & 0.3 & 0.3 & 0.3 \\
\hline
\end{tabular}

\begin{tabular}{|c|c|c|c|c|c|c|c|c|c|c|c|c|c|}
\hline \multirow{2}{*}{ Averages } & & \multicolumn{4}{|c|}{ Salinity (pss) } & \multicolumn{4}{|c|}{ Turbidity (NTU) } & \multicolumn{4}{|c|}{ Velocity $(\mathrm{m} / \mathrm{s})$} \\
\hline & & Mouth & Center & End & MS & Mouth & Center & End & MS & Mouth & Center & End & $\mathrm{MS}$ \\
\hline \multirow[t]{4}{*}{ Fluctuating flow } & mean & 0.4 & 0.4 & 0.4 & 0.4 & 24.6 & 21.6 & 20.1 & 25.3 & 0.02 & 0.04 & 0.02 & 0.13 \\
\hline & St dev & 0.074 & 0.043 & 0.043 & 0.045 & 16.64 & 14.01 & 15.64 & 19.7 & 0.028 & 0.034 & 0.04 & 0.142 \\
\hline & SE & 0.0 & 0.0 & 0.0 & 0.0 & 2.9 & 2.4 & 2.7 & 3.3 & 0.0 & 0.0 & 0.0 & 0.0 \\
\hline & CI (2SE) & 0.0 & 0.0 & 0.0 & 0.0 & 5.9 & 4.9 & 5.4 & 6.7 & 0.0 & 0.0 & 0.0 & 0.0 \\
\hline \multirow[t]{4}{*}{ Steady flows } & mean & 0.4 & 0.4 & 0.4 & 0.4 & 6.1 & $5.6 * *$ & 7.7 & $3.9 * *^{2}$ & 0.04 & 0.02 & 0.02 & 0.17 \\
\hline & \begin{tabular}{|l} 
St dev \\
\end{tabular} & 0.0 & 0.0 & 0.1 & 0.0 & 4.6 & 2.4 & 5.6 & 2.2 & 0.0 & 0.0 & 0.0 & 0.1 \\
\hline & SE & 0.0 & 0.0 & 0.0 & 0.0 & 0.8 & 0.4 & 1.0 & 0.4 & 0.0 & 0.0 & 0.0 & 0.0 \\
\hline & CI (2SE) & 0.0 & 0.0 & 0.0 & 0.0 & 1.6 & 0.9 & 1.9 & 0.8 & 0.0 & 0.0 & 0.0 & 0.0 \\
\hline
\end{tabular}

$* \mathrm{p}<0.05$ for one-tailed t-test of differences in means between habitats.

** $\mathrm{p}<0.05$ for one-tailed $\mathrm{t}$-test of difference in means between flow treatments within habitats.

Shoreline temperatures were significantly lower than backwater temperatures by

$1^{\circ} \mathrm{C}\left(t_{\text {treatment } 1(0.05,(1), 11)}=1.88, \mathrm{p}=0.037 ; t_{\text {treatment } 2(0.05,(1), 11)}=2.65, \mathrm{p}=0.007\right)$ during both 
treatments. Turbidity along the shoreline was significantly lower during steady flow treatment $\left(\bar{X}\right.$ turb $_{\text {backwater }}=6.48 \mathrm{ntu}, \bar{X}$ turb $\left._{\text {shoreline }}=3.87 \mathrm{ntu}, \mathrm{t}_{(0.05,(1), 11)}=2.27, \mathrm{p}=0.016\right)$.

\section{Benthic Macroinvertebrate and Phytoplankton Collections}

The density of benthic invertebrates in backwaters did not differ significantly between treatments $\left(\mathrm{t}_{(0.05,(1), 11}, \mathrm{p}>0.05\right.$; table 4$)$. In contrast, plankton densities were significantly higher during the fluctuating flow treatment $\left(\mathrm{t}_{(0.05,(1), 11)}, \mathrm{p}<0.05\right)$ in backwaters. Annelids were the most abundant species found in backwaters followed by Chironomid larvae and pupae (table 4; fig. 4a, b).
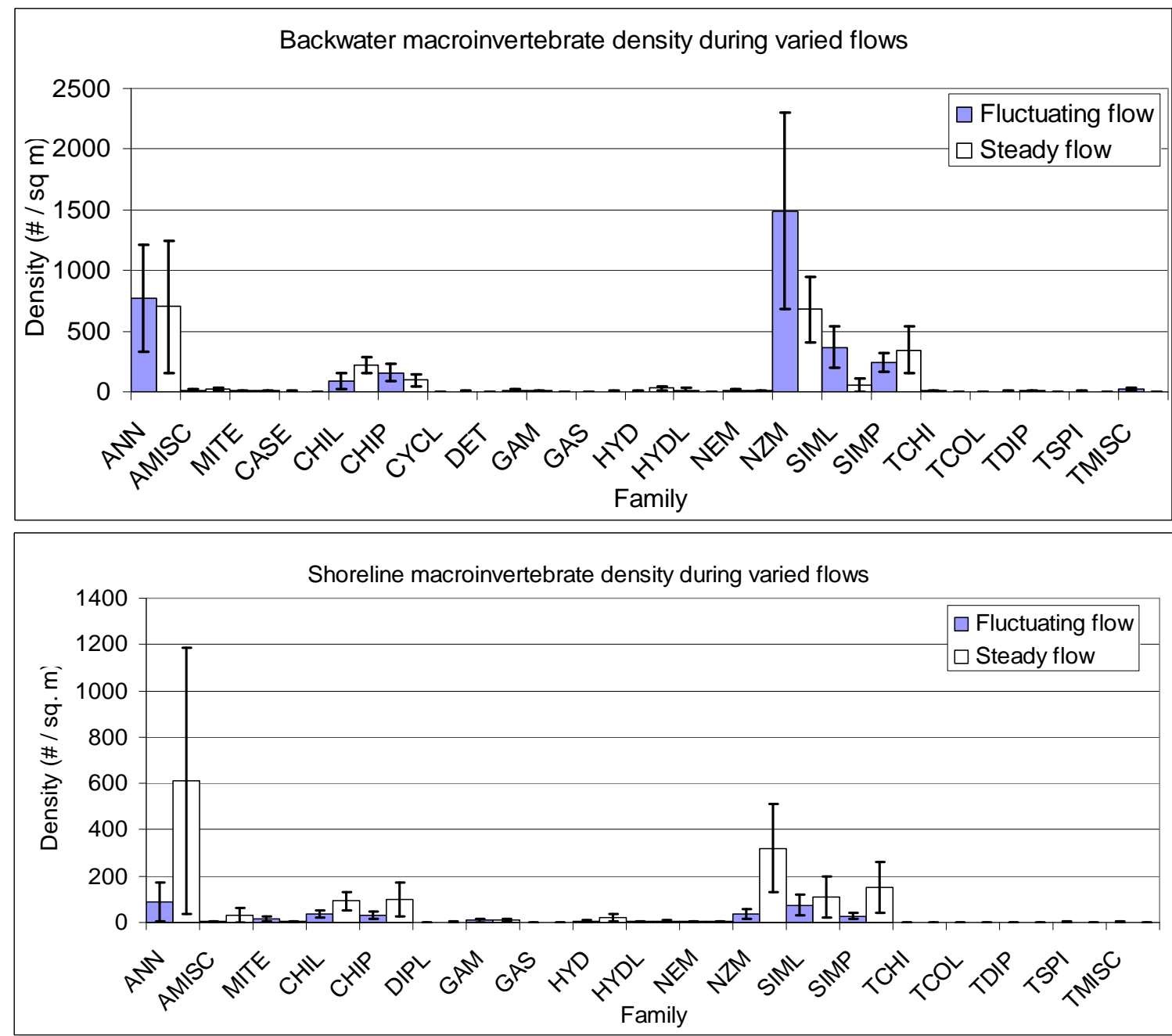

ANN=Annelida, AMISC=Aquatic Misc., MITE=Arachnida, CASE=Unknown case, CHIL=Chironomidae larvae, $\mathrm{CHIP}=$ Chironomidae pupae, $\mathrm{CYCL}=\mathrm{Cyclopedia}, \mathrm{DET}=$ Detritus, $\mathrm{DIPL}=$ Diptera larvae, GAM=Gammarus, GAS=Gastropod, HYD=Hydroptilidae case, HYDL=Hydroptilidae larvae, NEW=Nematoda, NZM=New Zealand mudsnail, SIML=Simulidae larvae, SIMP=Simulidae pupae, TCHI=Terrestrial Chironomidae, TCOL=Terrestrial Coleptera, TDIP=Terrestrial Diptera, TSPI=Terrestrial Spider, TMISC $=$ Terrestrial Misc.

Figure 4. Bar graphs comparing macroinvertebrate densities sampled from a.) backwaters and b.) shorelines during fluctuating and steady releases in September and October 2005 (abbreviations for taxa provided below fig. b). 
Table 4. Summary statistics of macroinvertebrate densities from backwaters and shoreline habitats under fluctuation and steady releases from September 4 to 0ctober 7, 2005 (abbreviations for taxa provided below table).

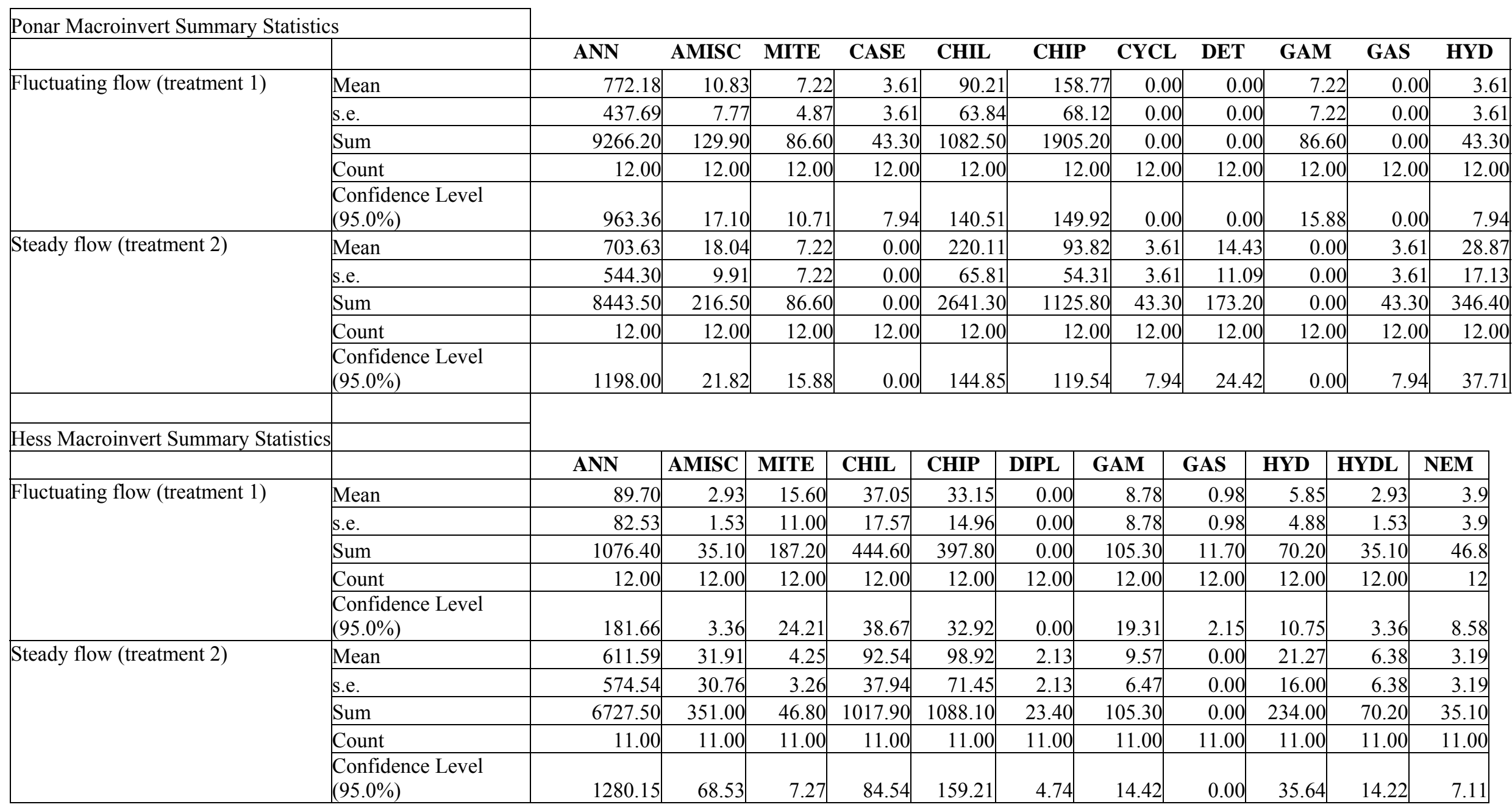


Table 4 continued

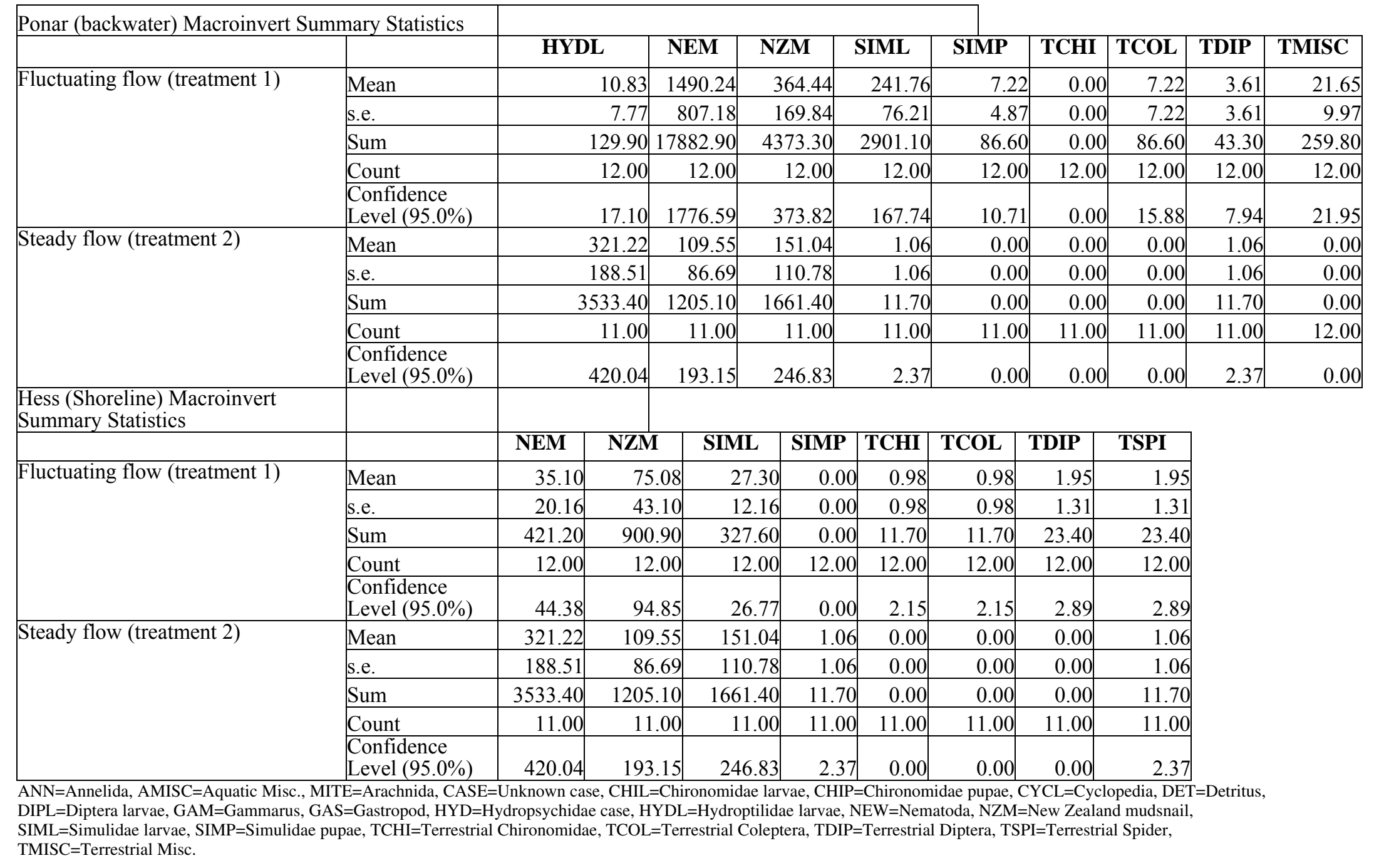


Benthic invertebrate densities along shorelines did not differ significantly between treatments $\left(\mathrm{t}_{(0.05,(1), 11)}, \mathrm{p}>0.05\right)$. Plankton density along shorelines was significantly higher during the fluctuating flow treatment $\left(\mathrm{t}_{(0.05,(1), 11)}, \mathrm{p}<0.05\right)$, a pattern similar to that found for backwaters (fig. 5a, b). Annelids were the most abundant species found in shoreline samples during both treatments, followed by Simulidae larvae and Chironomid pupae (table 4; fig. 4a, b).

a.
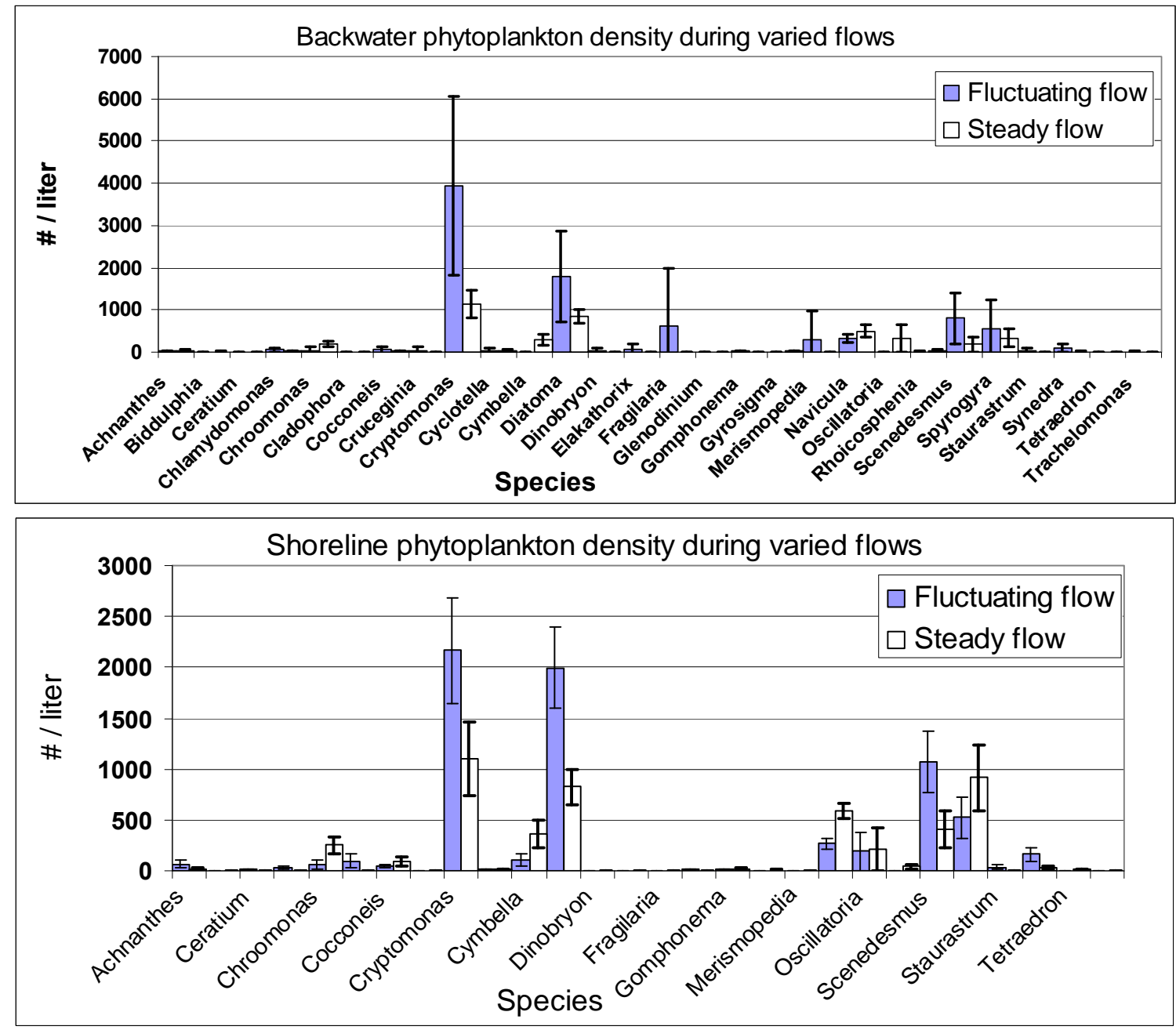

Figure 5. Bar graphs comparing phytoplankton densities sampled from a.) backwaters and b.) shorelines during fluctuating and steady releases in September and October 2005.

Although the number of individuals for particular species differed between habitats, benthic communities were similar based on a non significant result for the Mantel test for all comparisons between habitats and treatments $(\mathrm{p}>0.05)$. Patterns associated with benthic density with distance from the dam were similar between habitats (fig. 6a, b). 
a.

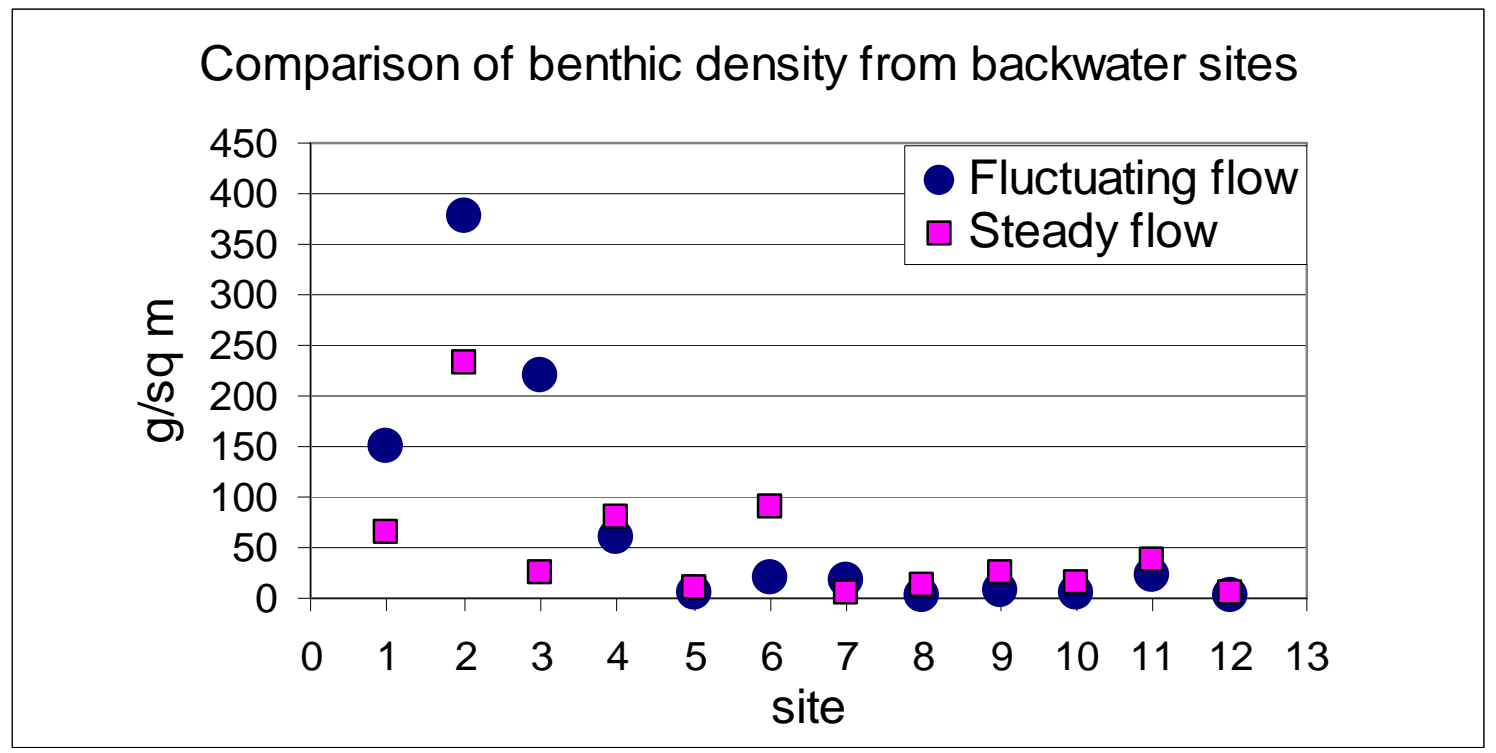

Comparison of benthic density from shoreline sites

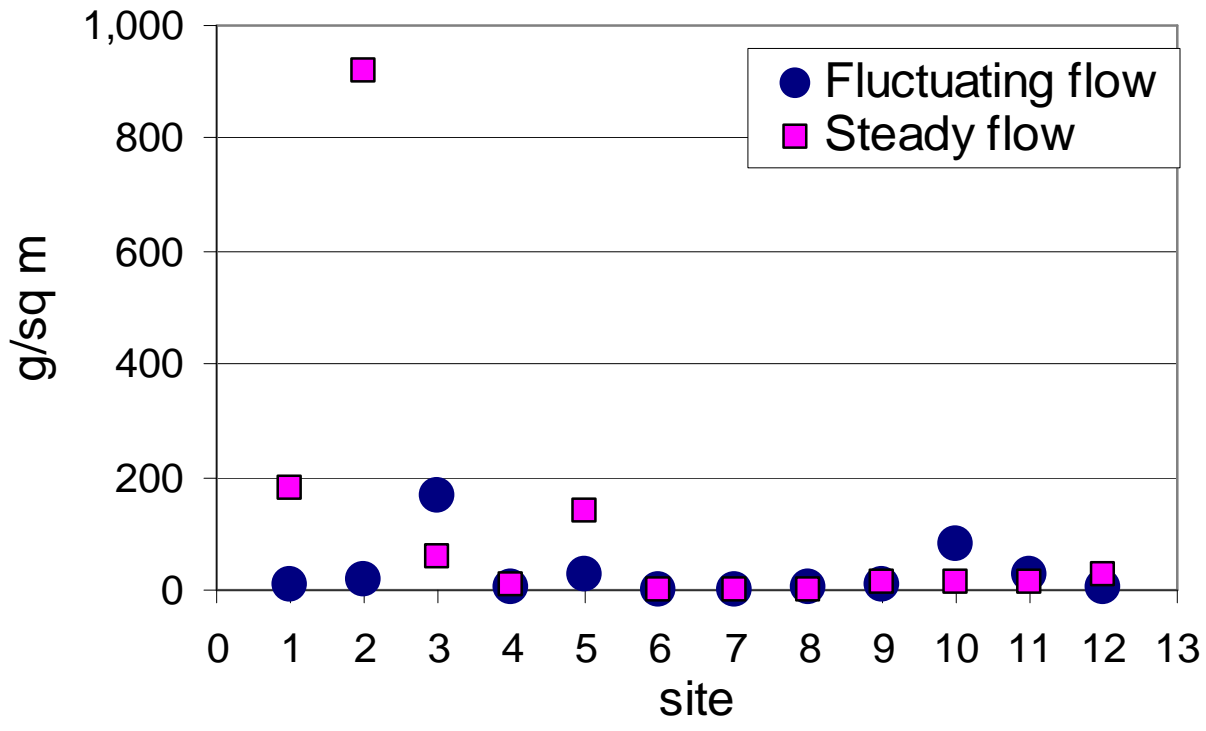

Figure 6 . Benthic invertebrate density by site under fluctuating and steady releases with distance from Glen Canyon Dam for a.) backwaters and b.) shoreline habitats (difference between treatments were non significant).

Fish Collections

The CPUE for all native fish (speckled dace, flannelmouth sucker, and humpback chub) was not significantly different in backwaters among sampling treatments $\left(\mathrm{t}_{0.1,(1), 11}, \mathrm{p}\right.$ $>0.05$; fig 7a) with the exception of bluehead suckers $\left(\mathrm{t}_{0.1,(1), 11}=1.92, \mathrm{p}=0.04\right)$. The 
CPUE was greatest at a site located above the Little Colorado River during the first treatment (Site 4, fig. 8a, b). Under the steady flow treatment, greatest CPUE was recorded below the Little Colorado River in Site 7 (fig. 8a, b) with CPUE showing an increasing trend from sample Sites 5 through 7 . There is a positive relationship between increasing CPUE with distance from the dam, but this was not significant. Fathead minnows were the most abundant fish, followed by flannelmouth suckers, during both treatments.

A.
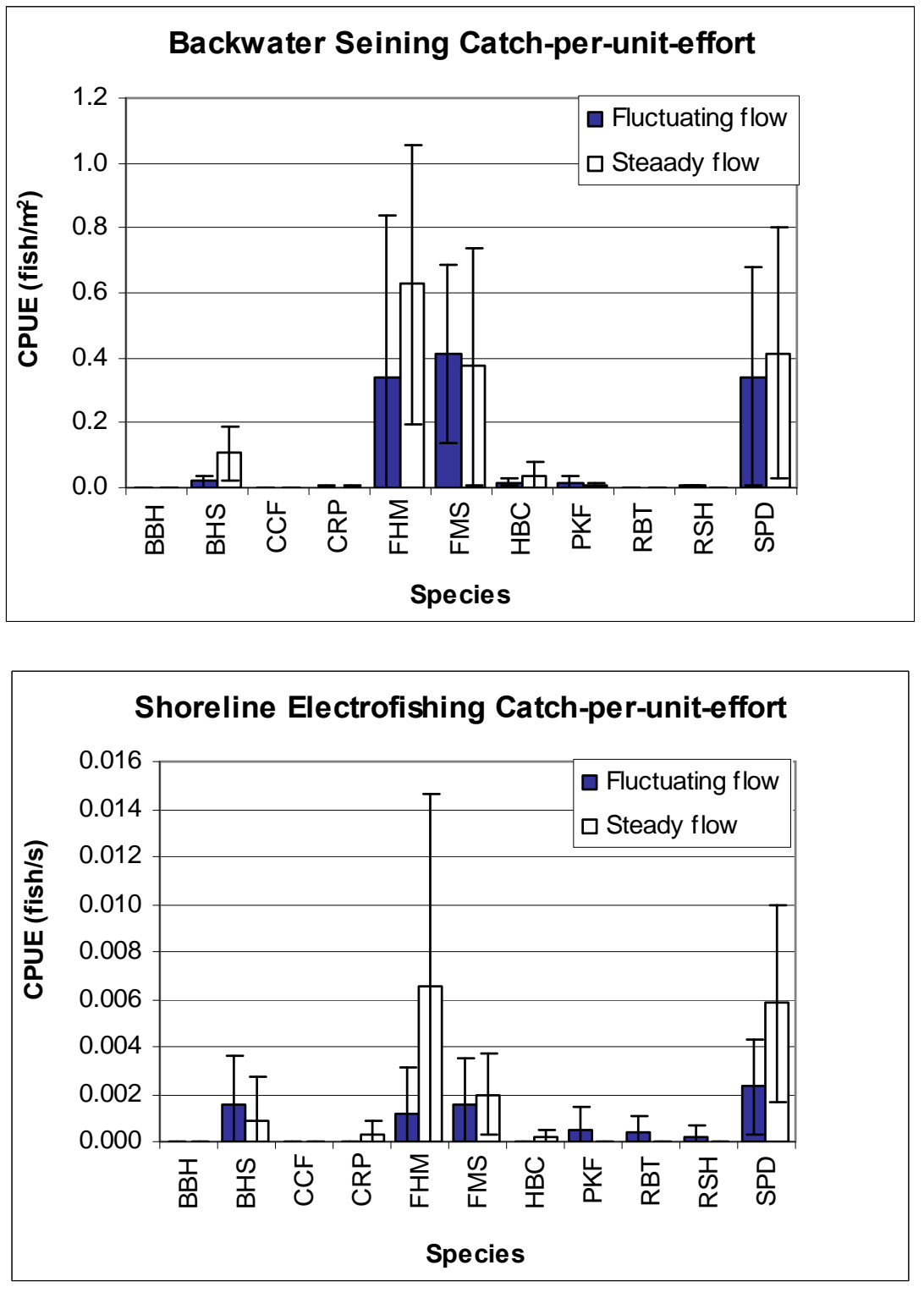

$\mathrm{BBH}=$ black bullhead, $\mathrm{BHS}=$ bluehead sucker, $\mathrm{CCF}=$ channel catfish, $\mathrm{FHM}=$ fathead minnow, FMS=flannelmouth sucker, $\mathrm{HBC}=$ humpback chub, $\mathrm{PKF}=$ plains killifish, $\mathrm{RBT}$ =rainbow trout, $\mathrm{RSH}=$ red shiner, $\mathrm{SPD}=$ speckled dace

Figure 7. Catch-per-unit-effort (CPUE) for fish species encountered from a.) backwater seining and b.) shoreline backpack shocking under fluctuating and steady releases in September and October 2005 (abbreviations for species provided below fig. b). 
a.

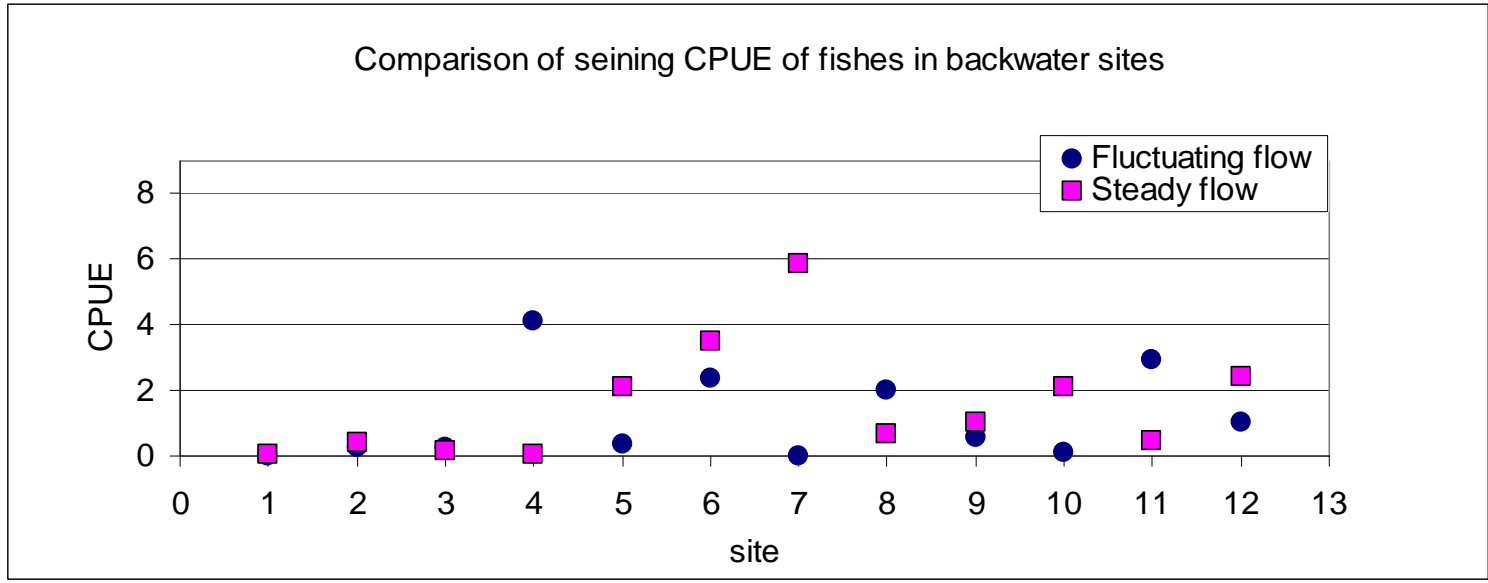

b.

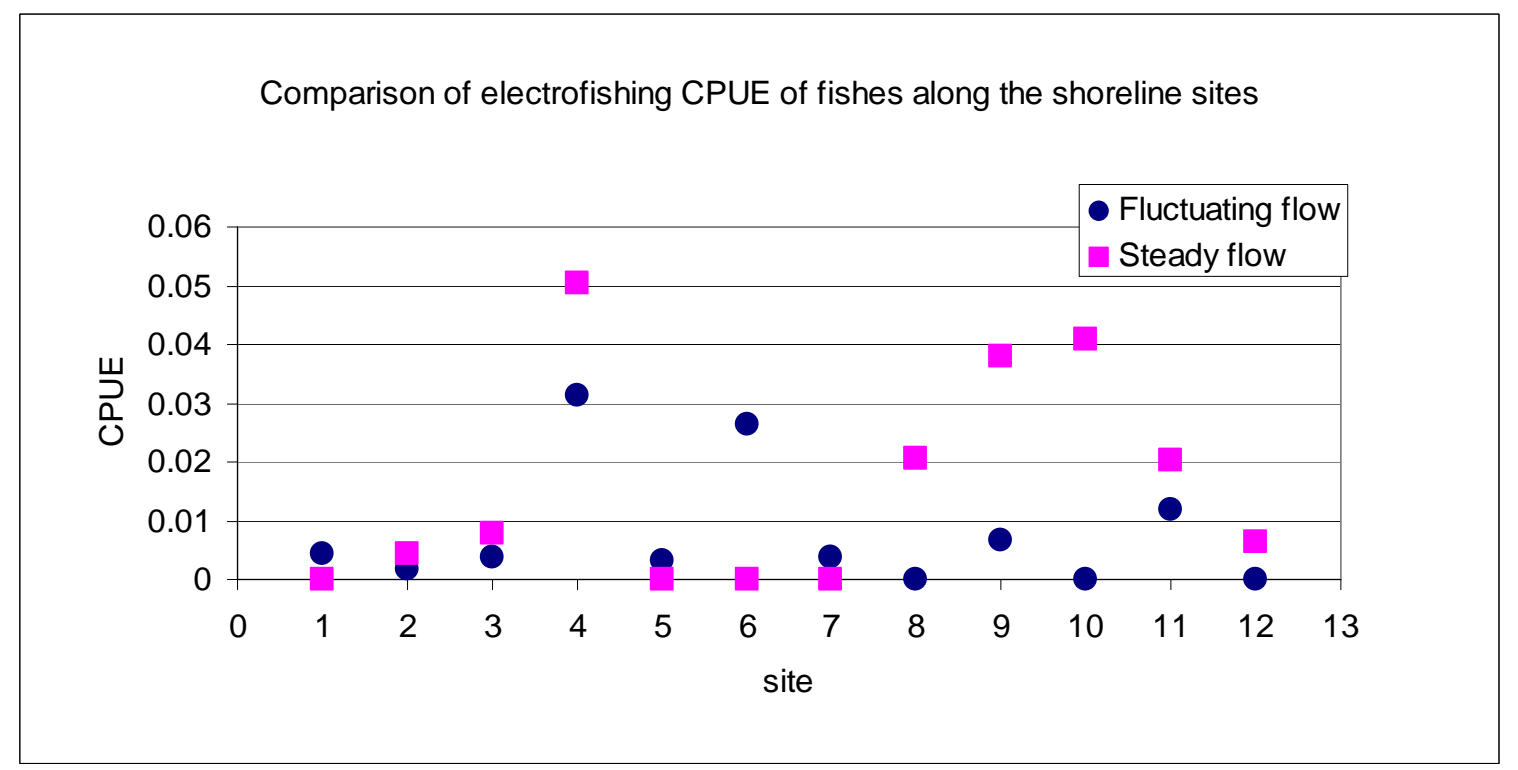

Figure 8. Catch-per-unit-effort (CPUE) for fish species encountered from a.) backwater seining and $b$.) shoreline backpack shocking under fluctuating and steady flow treatments with distance from Glen Canyon Dam (difference between treatments were non significant).

The CPUE for native fish did not change significantly during the two treatments along the shoreline. Speckled dace was the most abundant fish captured along the shoreline during fluctuating flows followed by fathead minnows (fig. 7b). During the steady flow period, fathead minnows were the most common fish species captured, followed by speckled dace. Total CPUE during the second treatment increased by $120 \%$. Although CPUE differed between habitats, fish communities were similar between habitats based on non significant Mantel test results for all comparisons between habitats and treatments $(\mathrm{p}>0.05)$. 


\section{Discussion}

Our results indicate that there were some differences in the water quality and biological parameters that we measured in backwaters and along shorelines between low fluctuating and steady flow treatments. Water quality parameters were not significantly different among treatments except for turbidity, which was significantly lower during the second treatment. This may be due to reduced tributary inputs during the second treatment rather than operations, however. Plankton density was greater during the fluctuating treatment than during the steady flow treatment, while macroinvertebrate densities were not significantly different among treatments. Total macroinvertebrate density was greater during the steady flow treatment, but the difference was not statistically significant. Macroinvertebrate communities did not differ between habitats or treatments, but invertebrate density was higher in backwaters relative to shorelines. The CPUE for native fish was also not different between these treatments except for an increase in bluehead suckers in backwaters during the steady flow treatment (fig. 7a).

Differences between habitat types were observed during both treatments. During fluctuating flows, backwaters were warmer than the shoreline habitat by $1^{\circ} \mathrm{C}$ as compared to during steady flows (table 3). Warmer temperatures in backwaters relative to other shoreline types have been reported elsewhere (Arizona Game and Fish Department 1996; Kaplinski, 2006; Korman and others, 2006). Water temperature was less variable during steady flows relative to fluctuating flows. This may have been due to shorter day length during the steady flow treatment, which limited the amount of warming, and hence variability in temperature, that could occur.

Under both treatments, macroinvertebrate densities declined in both habitats with distance from the dam (fig. 6 a, b). This pattern may be related to factors other than operations, but suggests further study may be warranted. Comparisons of species within habitats showed a pattern of increased densities among some macroinvertebrates (e.g., annelids, New Zealand mudsnails) along shoreline habitats under the steady flow treatment (fig. 4b), while there was a slight decline in the densities of some macroinvertebrates in backwaters (fig. 4a). While neither of these patterns were statistically significant they do suggest data collection under longer term flow treatments that compare habitats may be beneficial to understand food availability and habitat interactions.

Our results should be interpreted cautiously as the time within and between treatments was insufficient to determine the effects of flow alone on the sampled organisms. The combination of antecedent environmental conditions associated with summer operations, localized storm events, and life histories of organisms likely overwhelmed any measurable short-term effects of the two-week flow treatments. Larger volume releases prior to data collection associated with August operations, the gradual reduction in release volumes during the first three days of September, and inputs from tributaries contribute to ambiguities in interpretation of the results for each treatment period. Just as the first treatment's antecedent conditions included higher volumes, the second treatment's conditions were potentially influenced by these releases as well as by the previous two weeks of reduced flows. The lower plankton densities observed during the second treatment may be an artifact of the reduced flow volume initiated on September 4, 2005, while the first treatment's data, which immediately followed reduced 
releases, were still likely associated with plankton densities released under larger volumes prior to the treatment period. Tributary inputs may have also contributed to changes in plankton density. Because there was no period of equilibration allowed between treatments, interpretation of the results relative to flow treatments is limited.

Monsoonal rains that prompted tributary inputs likely contributed to increased turbidity values recorded during the first treatment. During the first treatment, both the Paria and Little Colorado Rivers had small spates that probably contributed to increased turbidity. The sediment inputs preclude determining the effect of operations on turbidity levels for these habitats. If the flow treatments had been extended past the time that monsoon rains were most probable to occur, then questions regarding water clarity and discharge pattern might be apparent.

With respect to macroinvertebrate densities, the effect of suspended sediment inputs that occurred during the first treatment cannot be excluded as a factor affecting densities of macroinvertebrates observed during either the first or second treatments. Moreover, the observed density differences, while not significant, may also represent system-wide variability that might be observed at any time. The Arizona Game and Fish Department (1996) reported that benthic invertebrate densities varied significantly between years, seasons, and reaches from 1991 to 1994, suggesting the variables observed from these two treatments may be typical rather than attributable to changes in flows. A study by Hofknecht (1981) indicates that lower velocities and deposition of detritus are more likely to occur in a return channel, and these conditions favor increased numbers of benthic invertebrates. These physical conditions were observed during the second treatment in this study. Had steady flows continued for a longer period of time, changes in invertebrate densities may have been greater than average for the season.

Small fishes exhibited similar variability in CPUE between treatments as was observed for macroinvertebrates. The variability in catch effort could be attributed to tributary spates potentially influencing spatial distributions more than short-term changes in flows. Increases in fish abundance coincided with locations below the Little Colorado River, a major tributary to the mainstem (Sites 4-12 for fluctuating flows; Sites 5-12 for steady flows; fig. 8). Fish introductions from tributaries associated with monsoonal storms confound our ability to assess flow variables independently. While we did observe some slight differences in temperature and CPUE between habitats and treatments, our ability to make general statements about how slight fluctuations versus steady flows might affect shoreline habitat variables is limited by the short time permitted for data collection.

\section{Recommendations}

To determine the effect of an experimental treatment, such as different dam operations, on organisms, whether phytoplankton or fish, treatments must be roughly equivalent in length to the life-span of the organism in question. The only organisms we studied that have life-spans of $\sim$ two weeks, the duration of the experimental treatments, were phytoplankton. Although we observed minor differences in fish CPUE and invertebrate densities among treatments, it is impossible to determine what effect the treatments have on food availability for fishes or fish growth and survival because the treatments were not of sufficient duration. 
If the objective of the experiment is to identify a directional response by an organism to a treatment, which is assumed for adaptive management purposes, then the data collected should be associated with life history parameters (e.g., mortality, survivorship, and reproduction). Collecting life history parameters for aquatic organisms in the Colorado River is difficult given the size of the watershed, the influence tributaries can have on mainstem interactions, and the transient nature of aquatic organisms. Life history studies related to flow treatments may be more amenable to laboratory or other controlled environments first and then applied in a large scale setting (e.g., the CRE) for longer periods of time.

A laboratory setting can control external variables and identify likely trends associated with a particular flow treatment that can be subsequently measured and reliably tested in a field setting. The lab setting may also be used to identify the length of time needed to execute a field-based effort, identify the minimum amount of change in flow (or other parameters) required to elicit a measurable response by the target organism, and identify the lag time of response by an organism. The identification of time requirements for treatment and response by a target organism promotes wellplanned field-based efforts that collect data that are trophically linked and may improve commitment on the part of stakeholders to longer-term flow treatments that are required to measure responses by biological organisms.

Alternative collecting methods may also be used in a field-based study. Sampling might be focused on specific reaches of the river rather than a system-wide approach. In this manner sample frequency per site could increase and possibly reduce variance around the samples. This would require a more concerted logistical effort than a systemwide approach, but the variability observed in the system-wide approach may be reduced by sampling fewer sites more intensively, and the information gained may be more useful for answering questions regarding flow effects on habitats of young fishes and aquatic food base linkages.

\section{Acknowledgments}

Funding for this work was provided through Interagency Agreement 02AA406750 from the Bureau of Reclamation to USGS/GCMRC and Cooperative Agreement 04WRAG0011 between GCMRC and SWCA Environmental Consultants, Inc. We thank Carol Fritzinger, GCMRC, for her logistic coordination associated with the field collection dates and Matthew Andersen, Scott Vanderkooi, and two anonymous reviewers for their comments that improved this document. Christy Parry provided valuable editorial assistance.

\section{References Cited}

Andrews, E.D., 1991, Sediment transport in the Colorado River basin, in Marzolf, G.R., ed., Colorado River ecology and dam management: Washington, D.C., National Academy of Science Press, p. 54-74. 
Arizona Game and Fish Department, 1996, Ecology of Grand Canyon backwaters: Final report to U.S. Bureau of Reclamation, Glen Canyon Environmental Studies, Cooperative Agreement 9-FC-40-07940, 155 p.

Goeking, S.A., Schmidt, J.C., and Webb, M.K., 2003, Spatial and temporal trends in the size and number of backwaters between 1935 and 2000, Marble and Grand Canyons, Arizona: Final report submitted to U.S. Geological Survey, GCMRC, Flagstaff, Ariz., Agreement 01WRAG0059, 24 p.

Gorman, O.T., and Stone, D.M., 1999, Ecology of spawning humpback chub, Gila cypha, in the Little Colorado River near Grand Canyon, Arizona: Environmental Biology of Fishes, v. 55, p. 115-133.

Griffiths, P.G., Webb, R.H., and Melis, T.S., 2004, Frequency and initiation of debris flows in Grand Canyon, Arizona: Journal of Geophysical Research, v. 109, p. 114.

Hofknecht, G.W., 1981, Seasonal community dynamics of aquatic invertebrates in the Colorado River and its tributaries within Grand Canyon, Arizona: Flagstaff, Ariz., Northern Arizona University, Masters Thesis.

Holling, C.S., ed., 1978, Adaptive environmental assessment and management (International series on applied systems analysis): New York, Wiley, $377 \mathrm{p}$.

Kaeding, L.R., and Zimmerman, M.A., 1983, Life history and ecology of the humpback chub in the Little Colorado and Colorado rivers of the Grand Canyon: Transactions of the American Fisheries Society, v. 112, p. 577-594.

Kaplinski, Matt, 2006, Near shore water temperature data-August 12 to November 14, 2005: Data report to U.S. Geological Survey, GCMRC, Flagstaff, Ariz., Cooperative Agreement 05WRSA0293, 23 p.

Korman, Josh, Kaplinski, Matt, and Buszowski, Joseph, 2006, Effects of air and mainstem water temperatures, hydraulic isolation, and fluctuating flows from Glen Canyon Dam on water temperatures in shoreline environments of the Colorado River in Grand Canyon: Final report to U.S. Geological Survey, GCMRC, Flagstaff, Ariz., Cooperative Agreement 04WRAG0006, Modification 1.

Korman, Josh, Kaplinski, Matt, Hazel, J.E., and Melis, T.S., 2005, Effects of the experimental fluctuating flows from Glen Canyon Dam in 2003 and 2004 on the early life history stages of rainbow trout in the Colorado River: Final report submitted to U.S. Geological Survey, GCMRC, Flagstaff, Ariz., Cooperative Agreement 04WRAG0006, Modification 002, 181 p.

Korman, Josh, Wiele, S.M., and Torizzo, Margaret, 2004, Modeling effects of discharge on habitat quality and dispersal of juvenile humpback chub (Gila cypha) in the Colorado River, Grand Canyon: Regulated Rivers, v. 20, p. 379-400.

McCune, Bruce, and Mefford, M.J., 1999, PC-ORD. Multivariate Analysis of Ecological Data. Version 5.0: Gleneden Beach, Oreg., MjM Software.

Melis, T.A., Martell, S.J.D., Coggins, L.G., Pine, W.E., and Andersen, M.W., 2006, Adaptive management of the Colorado River ecosystem below Glen Canyon, Arizona-using science and modeling to resolve uncertainty in river management, in Proceedings of the Specialty Conference on Adaptive Management and Water Infrastructure, June 26-28, 2006: Missoula, Mont., American Water Resources Association, p. 6. 
Robinson, A.T., and Childs, M.R., 2001, Juvenile growth of native fishes in the Little Colorado River and in a thermally modified portion of the Colorado River: North American Journal of Fisheries Management, v. 21, p. 809-815.

Rubin, D.M., Topping, D.J., Schmidt, J.C., Hazel, J.E., Kaplinski, Matt, and Melis, T.S., 2002, Recent sediment studies refute Glen Canyon Dam hypothesis: Eos Transactions, v. 83, no. 25, p. 273-278.

Schmidt, J.C., and Graf, J.B., 1990, Aggradation and degradation of alluvial-sand deposits, 1965 to 1986, Colorado River, Grand Canyon National Park, Arizona: U.S. Geological Survey Professional Paper 1493.

Stevens, L.E., Shannon, J.P., and Blinn, D.W., 1997, Colorado River benthic ecology in Grand Canyon Arizona, USA-dam, tributary and geomorphic influences: Regulated Rivers: Research and Management, v. 13, p. 129-149.

Stone, D.M., and Gorman, O.T., 2006, Ontogenesis of endangered humpback chub (Gila cypha) in the Little Colorado River, Arizona: American Midland Naturalist, v. 155 , p. 123-35.

Topping, D.J., Rubin, D.M., Schmidt, J.C., Hazel, J.E., Melis, T.S., Wright, S.A., Kaplinski, Matt, Draut, A.E., and Breedlove, M.J., 2006, Comparison of sediment-transport and bar response results from 1996 and 2004 controlled-flood experiments on the Colorado River in Grand Canyon: Proceedings of the 8th Federal Interagency Sedimentation Conference, April 2-6, 2006, Reno, Nev., 8p.

Topping, D.J., Rubin, D.M., Schmidt, J.C., and Vierra Jr., L.E., 2003, Computation and analysis of the instantaneous-discharge record for the Colorado River at Lees Ferry, Arizona-May 8, 1921, through September 30, 2000: U.S. Geological Survey Professional Paper 1677, 118 p.

Trammell, M.A., Valdez, R.A., Carothers, S.W., and Ryel, R.J., 2002, Effects of a low steady summer flow experiment on native fishes of the Colorado River in Grand Canyon, Arizona: Final report submitted to U.S. Geological Survey, GCMRC, Flagstaff, Ariz., Agreement 99-FC-40-2260, 77 p.

U.S. Department of Interior, 1995, Operation of Glen Canyon Dam-Final Environmental Impact Statement: Bureau of Reclamation, Salt Lake City, Utah, $337 \mathrm{p}$.

Vernieu, W.S., Hueftle, S.J., and Gloss, S.P., 2005, Water quality in Lake Powell and the Colorado River, in Gloss, S.P., Lovich, J.E., and Melis, T.S., eds., The state of the Colorado River ecosystem in Grand Canyon: U.S. Geological Survey Circular $1282,220 \mathrm{p}$.

Yard, M.D., Bennett, G.E., Mietz, S.N., Coggins Jr., L.G., Stevens, L.E., Hueftle, S.J., and Blinn, D.W., 2005, Influence of topographic complexity on solar insolation estimates for the Colorado River, Grand Canyon, AZ: Ecological Modelling, v. 183 , p. $157-172$. 